\title{
5. Photography and Propaganda
}

Today, the word 'propaganda' has negative connotations, often linked with manipulation and misuse of information. However, in the first few decades of the 20th century, it was understood as a structured process that used information to promote goals and drum up support. In this sense, it dealt with the control and transmission of information to an interested audience via the media. ${ }^{1}$ The media in question is often, but not always, the mass media, as shaped by various political, cultural and profit-related interests. ${ }^{2}$

Indeed, photography is basically information. As the French cultural critic Roland Barthes might have put it - photojournalism is a message defined by its information source, transmitter, channel, receiver and destination. ${ }^{3}$ From this perspective, the information source would be the members of a newspaper or magazine editorial board, the transmission channel would be the medium itself, and the receiver the audience. ${ }^{4}$ If we apply such a system to Partisan photography, we could say that the information source is the photographer, war photography unit or cultural unit, the editorial board of a certain newspaper, the printing house or the photography and propaganda department. The transmission channels are Partisan newspapers. In these newspapers it was supremely difficult to publish highquality photographic reproductions. Consequently, it was more common to see news boards containing clippings (photography alongside headlines and subheadings) or the developed prints of the photographs themselves. ${ }^{5}$ And while other contemporary authors such as Allan Sekula have claimed that photography cannot be observed alone outside the context in which it is distributed, here the entire context underpinning the function of Partisan photography and its messages must be laid bare. This is because we are not speaking here of newspaper editorial offices with a staff of photographers and editors at work in comfortable conditions. Instead, we are dealing with printing presses found mainly in hideouts in forests or in liberated towns and villages. Not infrequently, the photographers were also acting alone.

\footnotetext{
1 Aristotle Kallis, Nazi Propaganda and the Second World War, New York 2005, p. 1.

2 Sebastiaan Faber, Memory Battles of The Spanish Civil War, Nashville, p. 30.

3 Roland Barthes, 'The Photographic Message', in: A Barthes Reader, Susan Sontag (ed.), New York, p. 124

Ibid

5 The poor distribution channels for photography become manifest after a meeting of Allied Command for the Middle East on Yugoslav soil, as shown in a letter, dated 19 June 1943, sent by Slovene Partisan Edvard Kardelj to Boris Kidrič and Franc Leskošek, informing them that they need to make political use of their photographs and get them printed in the newspaper Poročevalec. Aware of the limitations of such publications, he advises them to take the images directly into the surrounding country and show them to the peasants in the villages. In: Zbornik dokumenata i podataka o narodno-oslobodilačkom ratu jugoslovenskih naroda, vol. II/7: Dokumenta vrhovnog štaba Narodnooslobodilačke vojske Jugoslavije 1942-1943, Belgrade 1959.
} 
When speaking of the context and channels of distribution, one interesting example is a photograph for which Chetniks posed together with German and Ustashe officers in Sanski Most, in a park where twenty-seven people had been hanged only a year earlier. ${ }^{6}$ Another interesting example is the photographs in which members of the Ustashe pose with Chetniks on 15 May 1942 in Banja Luka, a town in northern Bosnia. After the Partisans had got their hands on these photographs through their connections and supporters of the Partisan movement, they distributed them among the local population, which helped garner even greater support for the Partisan movement. Vilko Vinterhalter was charged with this task. He was head of agitprop for Bosanska Krajina, and later editor of Oslobođenje, a newspaper still in circulation today. ${ }^{7}$ Afterwards, the Ustashe units encountered increasing resistance from the local population. Stjepan Kovačević, the intelligence officer for the Fourth Infantry Division of the Independent State of Croatia, wrote about this in a report in great detail, as did a Chetnik colonel named Rade Radić: "The people attack us, me especially, violently, because of the concluded treaties. ${ }^{9}$

Agitation, intrinsic to guerrilla movements (including the Partisans), is based on the assumption that political ideas are disseminated in words, letters and by many other means, and that this dissemination garners critical support for direct actions, or helps achieve a given political goal. Propaganda was understood to be the planned dissemination of political principles and knowledge allowing people to understand those principles. Culture presupposed a corpus of 'all the material and spiritual achievements of a single people or humanity over a certain period."10 The 'Instructions for the Operations and Organisation of Agitprop in Primorje-Gorenje Division' stated that in all units - in each platoon, company, battalion, brigade and, ultimately, division: 'You should always bear in mind that our army is stronger the more the fighters know, that is, the more politically aware, better informed, culturally advanced they are, in contrast to the fascist army, which is stronger the less the soldiers in it know, that is, the less politically conscious and informed and the more culturally backward they are.'11 From its inception, the Communist Party of Yugoslavia believed culture and education to be an important aspect in the revolutionary struggle unfolding alongside the anti-fascist struggle. This idea is illustrated by slogans such as: 'Education leads to freedom'; 'Weapons aren't just guns and cannons, planes and tanks, but knowledge too'; and 'A book helps us gain freedom, freedom will ensure we win the book' [i.e., create a society that values literacy and education].12 These slogans affirm the emancipatory potential of a struggle in which knowledge and education are the prerequisites for human liberation.

\footnotetext{
6 Branko J. Bokan, Srez Sanski Most u NOB 1941-1945. godine. Sanski Most 1980, p. 445.

7 Stevo Samardžija, Četrnaesta srednjebosanska NOU brigada, Banja Luka 1983, p. 233.

8 Ibid., p. 233.

9 Arhiv VII, NDH (Independent State of Croatia), box 101, reg. no. 2/4-1; see also Stevo Samardžija, Četrnaesta srednjebosanska NOU brigada, Banja Luka 1983.

10 Zbornik dokumenata i podataka o narodno-oslobodilačkom ratu jugoslovenskih naroda, vol. IX/3: Partijsko-politička dokumenta 1943. godine, Belgrade 1967.

11 Ibid.

12 Quoted from: Branko Petranović, Istorija Jugoslavije 1918-1988, Belgrade 1988, p. 357.
} 


\section{The Consolidation of Agitation and Propaganda Work}

Agitprop became an increasingly important channel of communication for political agitation, emancipation and the struggle to create a new world, because of the opportunities it created for the easy transmission of messages via photography. Yet one of this book's key theses is that Partisan photography never entirely had a singular and exclusively propaganda-related function. This is because the centralised operations of the propaganda and cultural departments were only consolidated in the final two years of the war, in step with the combat-related and political tasks the Partisans had before them. In 1943 the agitation and propaganda apparatus began to be organised more systematically. A Culture and Education Committee was established, split into four sectors: political agitation, printing, cultural work and educational work. The latter two sectors included literacy-promotion, education, lectures, an amateur theatre section, choirs, a library, archival work and photography:

Each agitprop brigade, in line with the opportunities and resources available to them (photographers, cameras and materials) should have a photojournalist who films combat, parades, exercises, learning, relaxation, entertainment, the seizing of enemy goods, prisons, enemy losses, our victims and work from the level of the brigade headquarters to the individual fighters, etc. They should bear in mind that photographs are the most objective images and documents of our struggle and that they are of invaluable historical value. They are also brilliant propaganda material. Photographs from the front lines portraying the struggle itself are of particular importance. This work should be approached as a matter of urgency: if the brigades lack the materials, they should let the agitprop division know, and they should report the number of cameras the brigade has available to use. All such recorded material belongs to the division staff and will be handed over as undeveloped film. The film stock will then be developed, and copies will be guaranteed for the brigade archive, and individual photographs will be presented to deserving individuals. ${ }^{13}$

The above description clearly shows that an awareness of photography-as-proof already existed. The writer believed in the power and truthfulness of photography, and viewed it as a more powerful medium at that time than written words, especially in terms of its propaganda potential. Such agitprop departments started indexing visual material by theme, thus laying the groundwork for the emergence of photographic archives. As for the topics chosen, their approach is strikingly bottom-up and non-hierarchical, celebrating and documenting common activities rather than only recording major events and figures. Leisure is important, as is every soldier, irrespective of their position in the military hierarchy.

Most photography units were organised following the directive issued by Supreme Command on 13 December 1944 on the organisation of propaganda and cultural and educational work in the People's Liberation Army of Yugoslavia. The photography units had to work in unison with the propaganda department of the Supreme Command, as well as 
with the general staff of the divisions and brigades. Propaganda activity underwent its biggest upswing at the end of 1944. It permeated the entire military structure from the smallest formations, battalions and companies to the Supreme Command itself. The latter was now reorganised, with several new departments: propaganda, cultural and educational

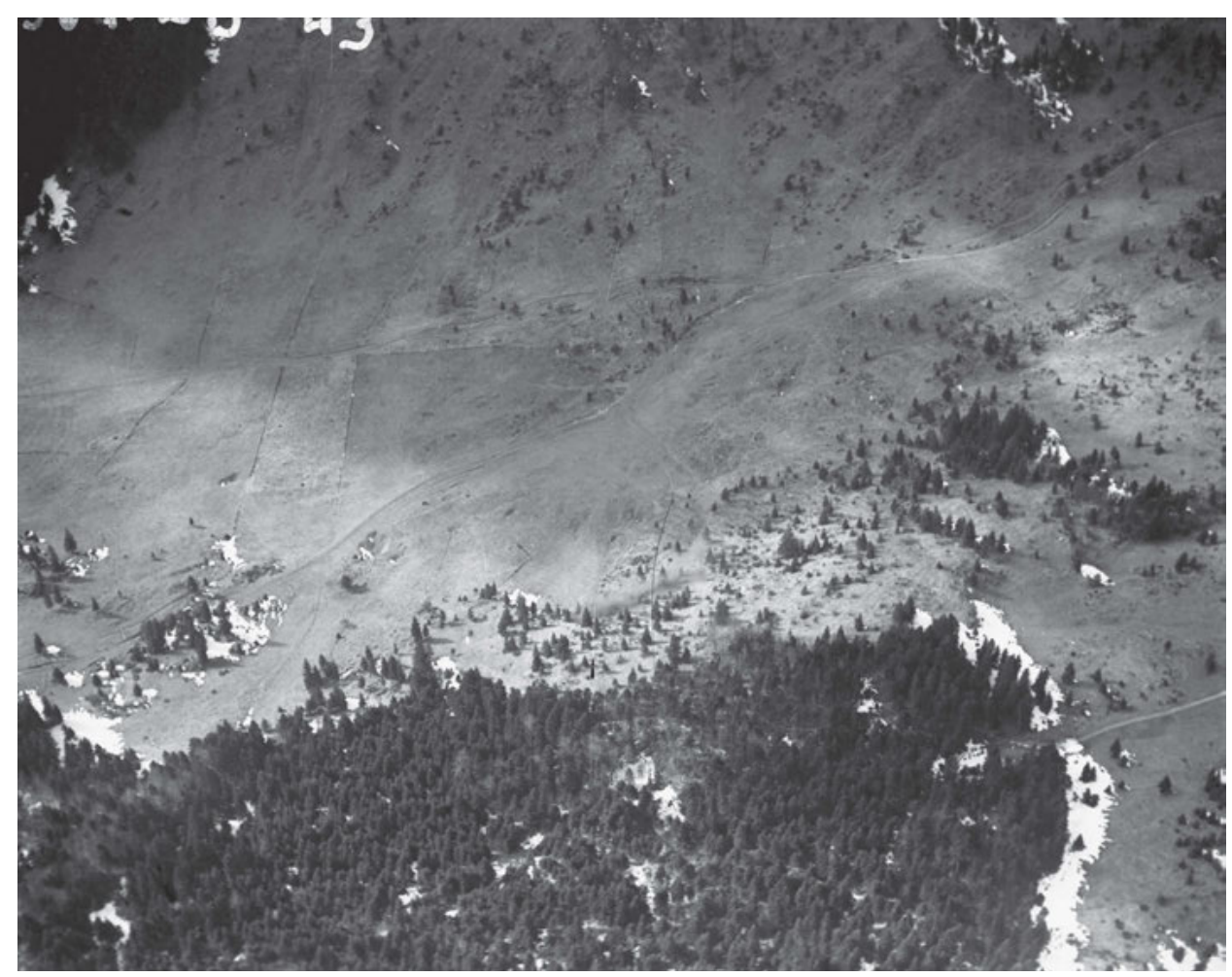

Uncaptioned. Most likely aerial reconnaissance from Allied plane, 1944-45. Photographer unknown. National Museum of Contemporary History (Slovenia), TN1119/8.

work, publishing, film, photography and historical and academic activities..$^{14}$ Criticism of this organisation structure was often directed at the 'one-size-fits-all approach to the various forms of work and the implementation of cultural and educational activities'.15 At the same time, the cultural departments within the brigades were the torchbearers for agitation and propaganda work, cultural activities and educational activities. During these years, an aerial photography unit was set up, which proved of vital use to the land surveying section. ${ }^{16}$ As Partisan aviation grew (the Partisans were the only resistance movement to form their own air force), so did the aerial photography unit, and its primary purpose was reconnaissance and intelligence. This was of crucial significance in preparing the final operations for the country's liberation. Aerial photos were enlarged and assembled into larger photomontages.

\footnotetext{
14 Ibid., p. 361.

15 Ibid., p. 362.

16 Zbornik dokumenata i podataka o narodno-oslobodilačkom ratu jugoslovenskih naroda, vol. V/26: Borbe u Hrvatskoj 1944. godine, Belgrade 1961.
} 


\section{4. Čega treba da se drže vojni cenzori u svome radu?}

Cilj rada vojnih cenzora treba da bude:

a) da spreče rasturanje knjiga,publikacija,filmova 1 odašiljanje pošte koji su po svome sadł̌aju upereni protiv tekovina naše borbe, usmereni na razaranje pozadine, demobilisanje snaga za ratne napore, izazivanje క̆ovinističkih $i$ sl.trvenja 1 sukoba, slabłjenje borbenog morala $i$ ratnih napora $i$ na to da neprijatelju otkrifju-svesno ili nesvesno - naše vojne tajne(položaj jedinica, obezbedjenje,brojno stanje,namere $i$ zadatke, o jacini i vrstama naoruźanja, vojne objekte za prebacivanje i smeštaj trupa,preduzeća za proizvodnju ratnog materijala $11 i$ vojne opreme,mesta 1 kapacitet nasih tvornica,brojno stanje radnika, podatke o predvidjenom putovanju, pravcu i načinu putovanja vojnih 1 politckih rukovodilaca,o mestima naših magacina, skladišta,načinu prevoza ratnog 1 vojnog materijala itd.).

b) da spece rasturanje svih knjiga, filmova, foto-materijala, publikacija, žurnala $i$ sl.Koji su proizvod fašisticke odnosno kvislinske propagande, $u$ kojima se pronose fašisticke tendencije, brane ili slave narodni izdajnici i sluge okupatora pa bilo da su one štampane, slikane ili snimane za vreme okupacije,pre okupacije ili posle oslobodjenja.

c) da spreče izdavanje i rasturanje,odnosno samo rasturanje stvari snimanih ili stampanih za vreme okupacije,koje bi štetile ratnim naporima savezničkih država ili išle na stetu - moralno ili materijalno I armija savezničkih država.Tako je odredjen opseg rada $i$ kriterijuma vojnih cenzora u cl.4 Uredbe $i$ njega se treba $\$$ potpuno pridržavati. Treba se Cuvati toga da vojni cenzori ne postunu kočnica književnog $i$ umetnickog razvoja.Za eenzore treba da bude bitno ne da 11 je neka stvar nla dovoljnoj umetničkoj visini, nego da li je ona neprijateljska ili fašisticka. Pogrešno bi bilo da vojni cenzori

Letter headed 'What must military censors consider in their work?', People's Liberation Army of Yugoslavia, Military Archive Belgrade, K460C F2 20.

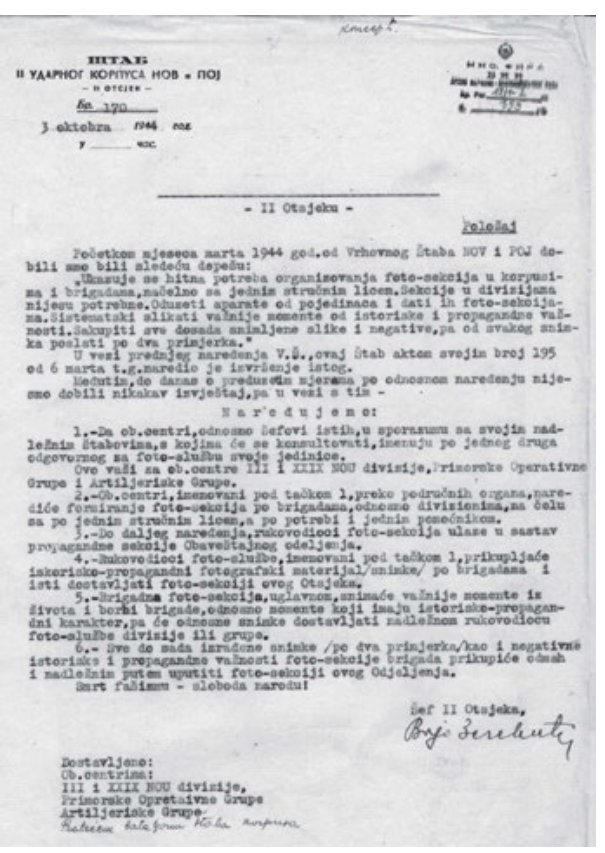

Instructions issued by General Staff on setting up photography units in the corps and brigades, 3 October 1944, Military Archive Belgrade, NOVJ K393 F2 19.

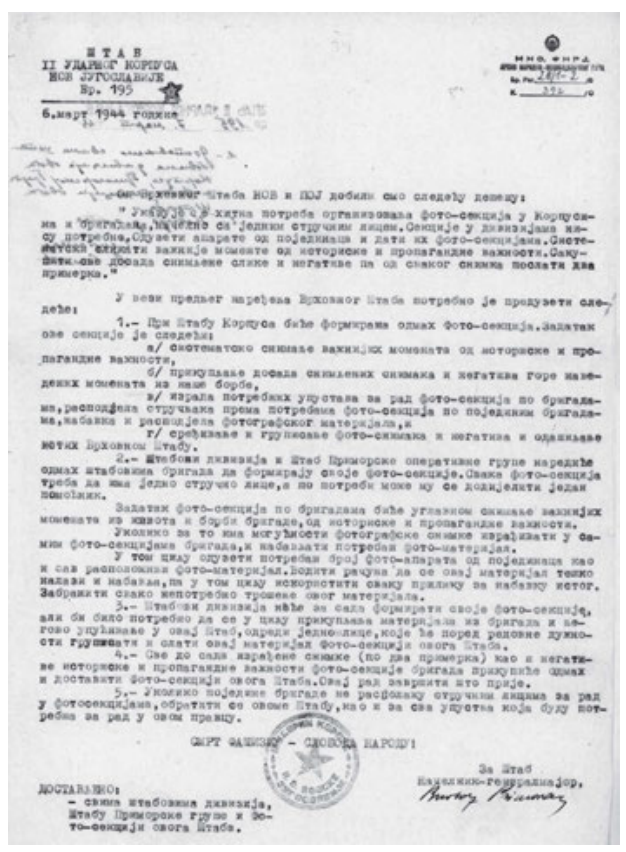

Instructions issued by General Staff on setting up photography units in the corps and brigades, 6 March 1944, Military Archive Belgrade, NOVJ K392 F2 28. 
The instructions for the correspondence service, written in March 1944, state that photographs are particularly important and that the correspondent's task is to gather all photography from the People's Liberation Movement, as well as photographs illustrating the consequences of enemy campaigns. Optimism was the order of the day, and the rules stated that Partisans should gather photographs in 'people's pockets, who will - for the needs of the movement - happily hand them over'. ${ }^{17}$ The Supreme Command thus issued the order on 4 March 1944 to the General Staff of the NOV i POJ (People's Liberation Army and Partisan Detachments of Yugoslavia) stating that the brigades and the corps must each set up their own photography unit that would record significant events, and that they should do so urgently. As for any individuals in possession of a camera, they ordered that their cameras be requisitioned and handed to the photography units: 'Take photographs in a systematic manner of the more important moments of historical and propaganda-related importance and collect all the pictures shot so far, including negatives, sending two copies of each picture. ${ }^{18}$ The same order reached the remaining staffs over the following few days, and furthermore demanded of them to draft clear instructions and missions for each photography units' work.

The changes that gradually occurred in the propaganda and agitation apparatus led to the Communist Party of Yugoslavia deciding to establish a new propaganda service, with attempts made to centralise propaganda efforts in 1944:

The starting premise of the new organisation of the agitprop service of the Central Committee aimed at overcoming 'spontaneity and backwardness', at building an apparatus for propaganda and agitation, concentrating - directly or indirectly - the entire people's political, cultural, educational and intellectual life in the hands of Party institutions with the goal of generating mass Party membership and establishing the ideological basis of the new society. ${ }^{19}$

The final year of war and its end were a turning point for photography, which came under the complete control of the mass apparatus. After this point, we incrementally entered a period that the historian Branko Petranović has described as a period without 'critique, debate, plurality of viewpoints in the field of cultural creativity, except for the odd critically worded piece of a political nature issued from within the ranks of the "civic opposition". ${ }^{20}$ This was the moment when Partisan photography fell into the hands of a centralised service. It would become an institution within the newly formed state that was attempting to establish sovereign control, including through the construction of dogmatic ideological positions across all of society. One of the reasons for such a turnaround is the fact that establishing a new state does not occur without resistance, or without problems, both in the country and abroad. After all, the Soviet Union presented a real threat of potential invasion.

17 Zemaljsko antifašističko vijeće narodnog oslobođenja Hrvatske, zbornik dokumenata 1944 (od 10. svibnja do 31. prosinca), 
In 1945, the propaganda departments within the staffs of each brigade and division had their own section for political propaganda, a section for culture and education, a section for photography, as well as a press department. The propaganda department of each corps, meanwhile, had (like those of the brigades and divisions) a department for political propaganda and one for culture and education, but they also had their own sections for school learning, literacy courses and art, as well as departments for press reportage, film and photography. The Supreme Command of the NOV i POJ (from 1 March 1945 the General Staff of the Yugoslav Army) had a department for political propaganda and a department of culture and education. The latter had three sections: general education, literacy courses and artistic activities. There were also press departments, an institute for researching the People's Liberation War, a photography unit, and a department for foreign relations and personnel affairs.

Despite views commonly held today, military censorship was only introduced at the beginning of 1945 and was intended to control information-sharing within the army According to the Supreme Command's documentation, the censors were established by the general staffs, and applied to the staffs of the corps and the corps' military fields and, when necessary, to the staffs of the brigades and detachments, too. The military censors fell under the command of the staffs, with a separate section tasked with censoring military postal correspondence. For the first time ever, there was an official list of forbidden books Manuscripts and books arriving from abroad were tracked, and more detailed descriptions of their contents had to be given. There was a special list for movies. Besides their detailed description, reasons for their censorship had to be listed. Interestingly, no seized materials were allowed to be thrown away because of the scarcity of materials. Instead, they had to be preserved and, if necessary, later recycled. Censorship did not cover official letters, such as those of members of the Supreme Command, or letters by civilians to other civilians or soldiers. However, it did cover the journalists' reports, those of all correspondents and photographs sent to various official publications.

The aim of censorship was to prevent the distribution of enemy literature and quisling propaganda, the disclosure of military secrets and the distribution of material printed during the occupation that would in any way threaten the efforts of Allied units. The military censors were explicitly told not to stifle literary and artistic talent and that their task was not to assess the artistic merit of written or visual material, but instead to decide whether such works had an inimical or fascist intent. ${ }^{21}$ In contrast to other military formations, both Allied and enemy, the censorship apparatus only came into being in the final year of war. As concerns photography, this is important because it was precisely the lack of coordinated supervision that contributed to the pluralism of ideas and approaches in style. Besides the difficult conditions of production, this pluralism was one of the most powerful defining features of Partisan photography. Broadly speaking, the democratic quality of the medium itself and of photographic production granted photographers a degree of autonomy from the authoritarian and bureaucratic practices that reigned 
elsewhere. Partisan photographers within the anti-fascist movement perhaps came closest to the ideal of a horizontal, 'bottom-up' anti-capitalist struggle in the sense that prevails today in various social movements the world over.

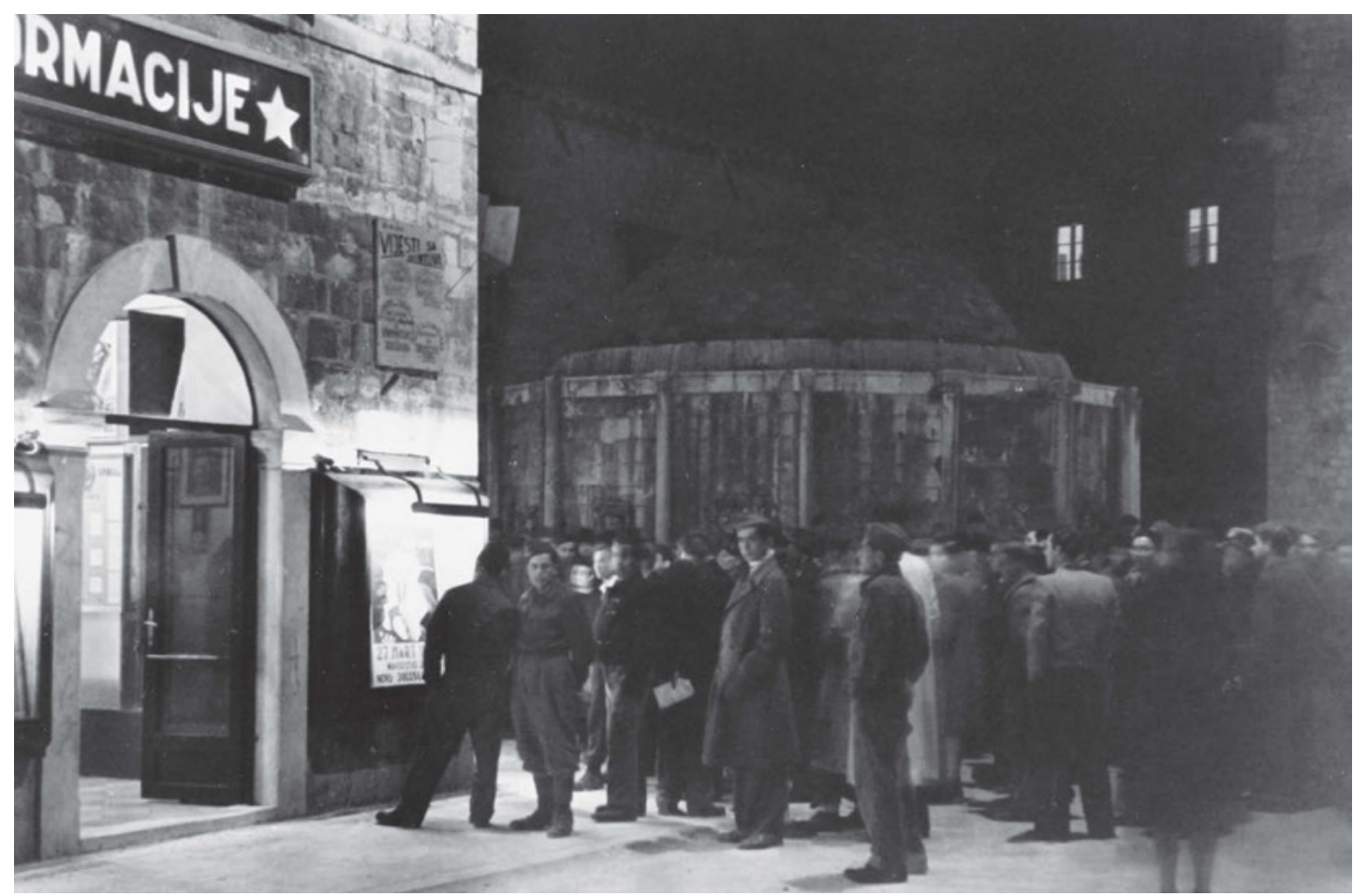

Waiting for radio news broadcast in front of the information office, Dubrovnik, 1945. Photo: Nikola Rupčić. Croatian History Museum, HPM/MRNH-F-8242.

\section{Enemy Propaganda}

Throughout the whole war, cultural and educational life on occupied territory was dedicated to fascist ideology and National Socialism, while the specific materials available were markedly anti-communist, antisemitic, and anti-Masonic. In the Independent State of Croatia they were also markedly anti-Serbian and anti-Yugoslav. German culture and Roman civilisation were glorified, and German, Italian, Bulgarian and Hungarian introduced as core languages. ${ }^{22}$ Under the Italian occupation, an Institute of Fascist Culture was established in Split. 
In occupied Serbia, one of the biggest propaganda exhibitions negatively depicting the influence of Freemasons, communists and Jews was the Anti-Masonic Exhibition, organised by journalists with pro-fascist proclivities such as Milan Stojadinović (head of the propaganda department of the Government Presidency during occupation), and Đorđe Perić, head of state propaganda. ${ }^{23}$ On posters and in the narratives of German - and especially quisling - propaganda in Yugoslavia, Partisans were depicted as arsonists and sexual perverts, prepared even to kill their own brothers.

In the Independent State of Croatia, photography fell under the responsibility of the State Reporting and Propaganda Office, ${ }^{24}$ led from 1941 to 1943 by the writer and photographer Ivan Softa, with help from the head of the film department, Mladen Grčević. ${ }^{25}$ The office's task was to gather all material for propaganda; by 1942 their picture library contained 3,000 photographs and negatives. ${ }^{26}$ In autumn of 1943, a new propaganda structure was established under the Main Directorate for Propaganda. This included a department of printing and photography, in turn subdivided into a department of journalism, of photography and of film. ${ }^{27}$ Propaganda photobooks were also published, such as Lijepa naša domovino (Our Beautiful Homeland). We can observe how propaganda functioned in the Independent State of Croatia by taking as an example the photographer Edmund Stoger, who was sent on assignment to Jasenovac concentration camp in early September $1942 .{ }^{28}$

Besides taking photographs during his eight-day-long stay in Jasenovac, Stoger filmed the propaganda film Pozitivni rad u logoru Jasenovac (Positive Work at the Jasenovac Concentration Camp), which was screened at the Zagrebački zbor, or ZZ, an autumn fair in Zagreb, that same year. Using the slogan 'Their earlier work was politics - our present-day politics is work', the fair even featured a replica of the barracks that simulated the conditions of life in the camp and its allegedly work-based and remedial character. The accompanying display showed artwork produced in incarceration, including drawings by the young Daniel Ozmo who was shot in September 1942, only a few days after his mother, brother and sister were also killed in Jasenovac. ${ }^{29}$ Stoger shot propaganda stills in Jasenovac that did not show the camp's brutal conditions, or its primitive 'manufacturing', whereby it made use of the 'handicraft of the most developed form of cruelty'. ${ }^{30}$

The exhibition was shown in the original shed that had served as sleeping quarters for the camp prisoners. The shack was fenced off with wire on the outside, and a guard post was placed in each part in which the Ustashe kept guard. Indeed, the exhibition strived to give the most faithful picture, with everything organised just as it was in the concentration camp. At the entrance to

\footnotetext{
23 Milan Radanović, 'Antimasonska izložba', in: Mesta stradanja i antifašističke borbe u Beogradu 1941-44. Priručnik za čitanje grada, Milovan Pisarri and Rena Rädle (eds.), Belgrade 2016 (Rosa Luxemburg Stiftung Southeast Europe), p. 74.

24 Croatian: Svjetlopisni ured Državnog izvještajnog i promičbenog ureda.

25 Branka Hlevnjak and Rhea Ivanuš, Hrvatska antiratna fotografija: Prvi svjetski, Drugi svjetski i Domovinski rat, Zagreb 2008, p. 101.

26 Nataša Mataušić, Koncentracioni logor Jasenovac, Zagreb 2008, p. 46.

27 Alan Labus, 'Upravljanje medijima, cenzura, te položaj i uloga novinara u Nezavisnoj Državi Hrvatskoj', in: Studia lexicograph-

ica, god. 3, no. 1-2(3-4), Damir Boris (ed.), Zagreb 2009, pp. 107-108.

28 Mataušić 2008 (see note 26), pp. 28-29.

29 Raphael Israeli, The Death Camps of Croatia: Visions and Revisions, 1941-1945, New Brunswick, New Jersey 2013, p. 166

30 Mataušić 2008 (see note 26), pp. 171-172.
} 
the shed where the exhibition was located, there was an Ustashe coat of arms, and beneath it the inscription: 'All for the leader [Ante Pavelić] - the Ustashe Defence.' [...] For years, Jews, Freemasons, and various other people like them have been a burden on the Croatian people. They have become absorbed into the lifeblood of the people, wishing to exploit the Croatian people as much as was humanly possible, to their own ends. This sea of people has placed a great strain on all our Croatian social strata, a sea it was impossible to defend oneself against, because those in power in Croatia at that time were themselves in their pockets, collaborating with them all the time, even when they were acting to the detriment of the Croatian people [...]. The exhibition Godinu dana sabirnih logora Ustaške obrane (One Year of the Concentration Camps of the Ustashe Defence) attracted the most attention among visitors to the $Z Z$. The wooden building in which the exhibition was located was constantly well attended and visitors looked around the various parts of the exhibition with particular interest. All necessary objects were purpose-built on site. One example is the bricks laid to make an oven for the camp to use, because they couldn't find the right kind of oven anywhere else. ${ }^{31}$

At the same time, the photographer Vice Lisičić was one of the few people granted permission to photograph the office of the Ustashe leader Ante Pavelić. ${ }^{32}$ Speaking of taking Pavelić's portrait, Lisičić said:

Taking Pavelić's photo portrait was nothing but trouble, as in all photographs he came out just as he really was: gloomy and with that well-known gangster-like expression. Of course, his wife, Mara (dubbed 'the pharaoh's wife'), didn't like the photos so the shooting was repeated indefinitely on her explicit orders until the 'gracious Führer' got sick and tired of it all. Finally, she arrived at a solution about how best to make her husband look gentle in front of the photographers; she ordered that jokes be told to him while posing. I only ever noticed a natural smile on his face in other situations, when looking at his beloved son Velimir riding a horse or playing the violin. ${ }^{33}$

Ustashe propaganda spoke of the Partisans' moral degeneracy, with Jews leading the movement. One Ustashe ideologue, Julije Makanec, said that Partisan women had been stripped of their motherly function, claiming them to be former prostitutes, and 'unstable women who defied their female instincts and motherly role. ${ }^{34}$

During the war, photographers in Zagreb continued their activities. In 1941, Fotoklub Zagreb put on the exhibition 'Our Beautiful Homeland' (accompanied by the eponymous publication mentioned above), with over 400 photographs on show. In occupied Slovenia, meanwhile, many Slovene Home Guard, Italian and German magazines were published. The first issue of the magazine Slovensko domobranstvo (Slovene Home Guard) serves as a striking example of photography seized from the Partisans and misappropriated. The issue includes an

\footnotetext{
31 Hrvatski narod, Njihov prijašnji rad bila je politika - sadašnja naša politika jest rad, 9. IX. 1942, no. 524; see also Nikica Mihaljević, 'Krvavi ustaški Disneyland: Srbi su lijeni, Židovi drski', in: Express, URL: (.express.hr/life/krvavi-ustaski-disneylandsrbi-su-lijeni- zidovi-drski-5978\# (accessed 17 February 2017).

32 Hlevnjak/Ivanuš 2008 (see note 25), p. 105.

33 Aleksandar Vojinović, Ante Pavelić, Zagreb 1988, p. 16.

34 Rory Yeomans, Visions of Annihilation: The Ustasha Regime and the Cultural Politics of Fascism, 1941-1945, Pittsburgh

2013, pp. 315-316.
} 
article, entitled 'The Communist Bourgeoisie and Their Proletariat', which attempts to discredit the poet Matej Bor by showing him in a bourgeois and faintly bohemian setting, holding a bottle of wine and surrounded by young women.

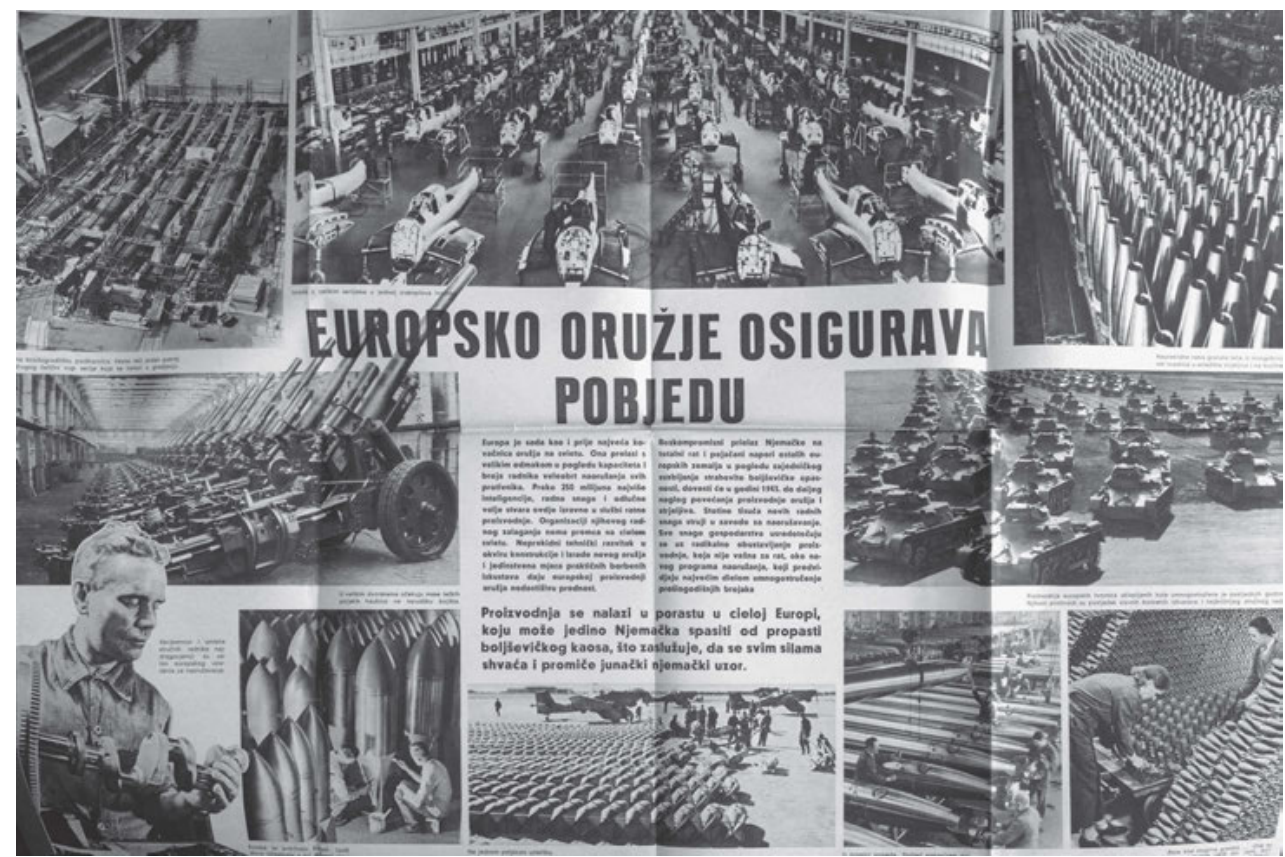

'European Weapons Secure Victory' poster. Archive of Bosnia and Herzegovina, FOND NDH.

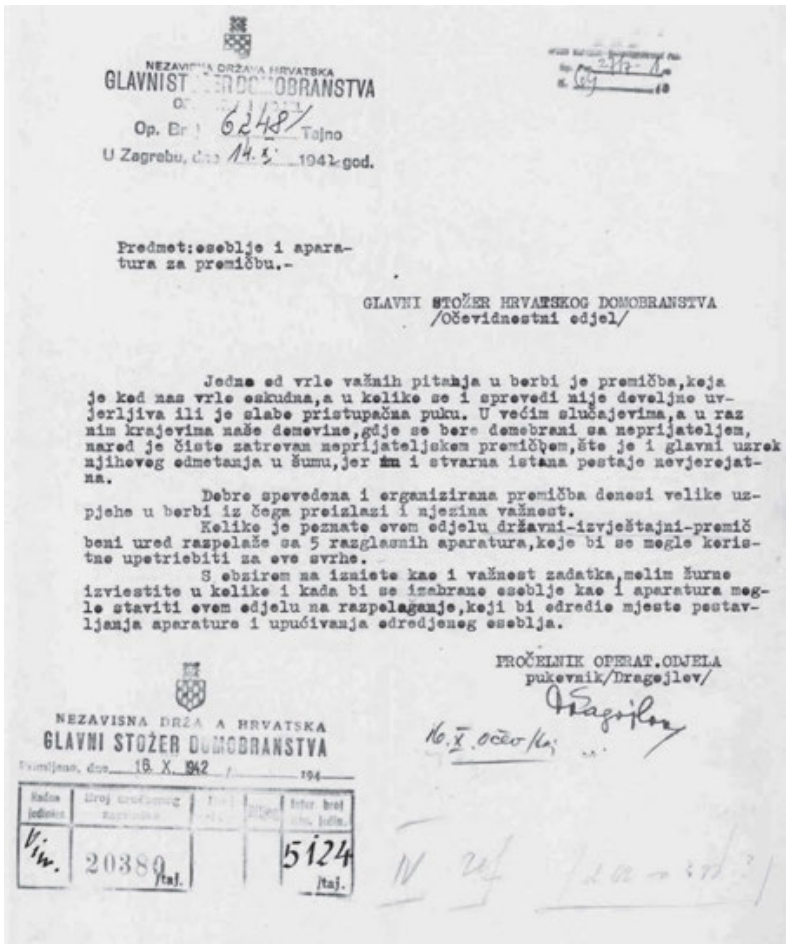

Propaganda appeal issued by General Staff of the Independent State of Croatia. Military Archive Belgrade, NDH K69 F7 27. 


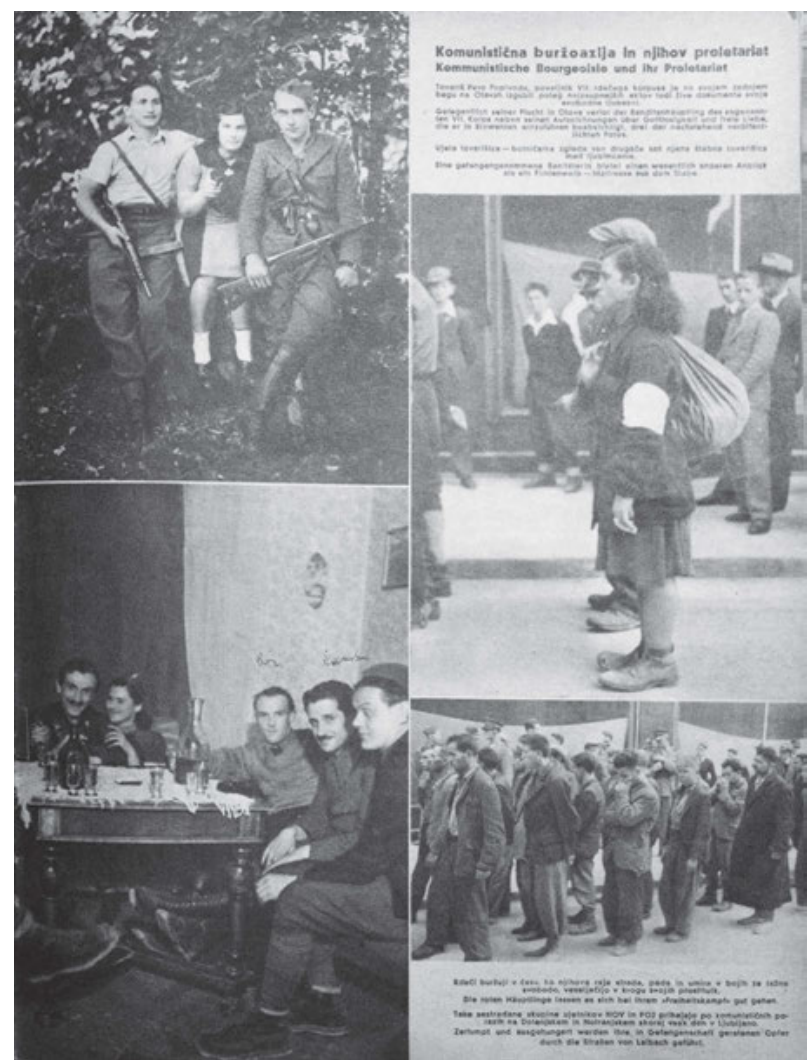

Slovene Home Guard, issue 1. Institute of Contemporary History (Ljubljana), accession no. unknown.

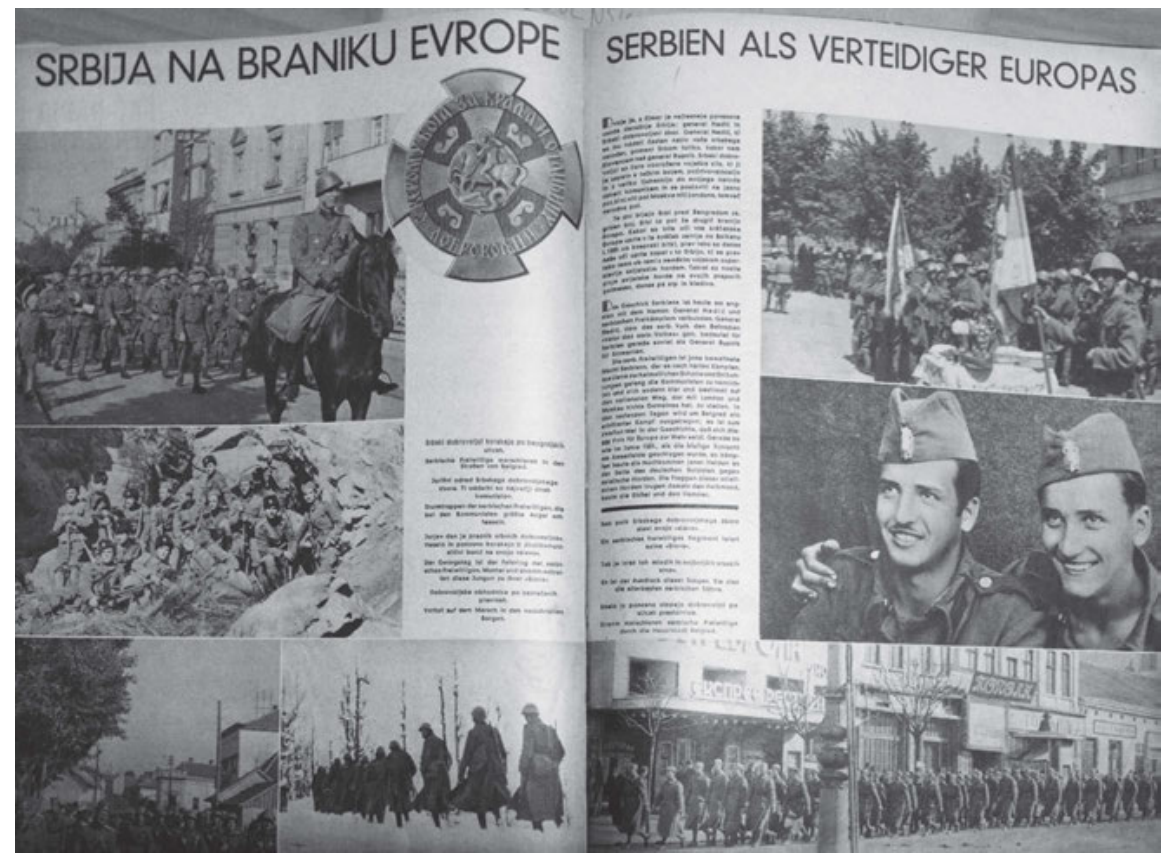

Double-page spread, 'Serbia as Defender of Europe', from Signal magazine, published in Serbian and German. Date unknown. 


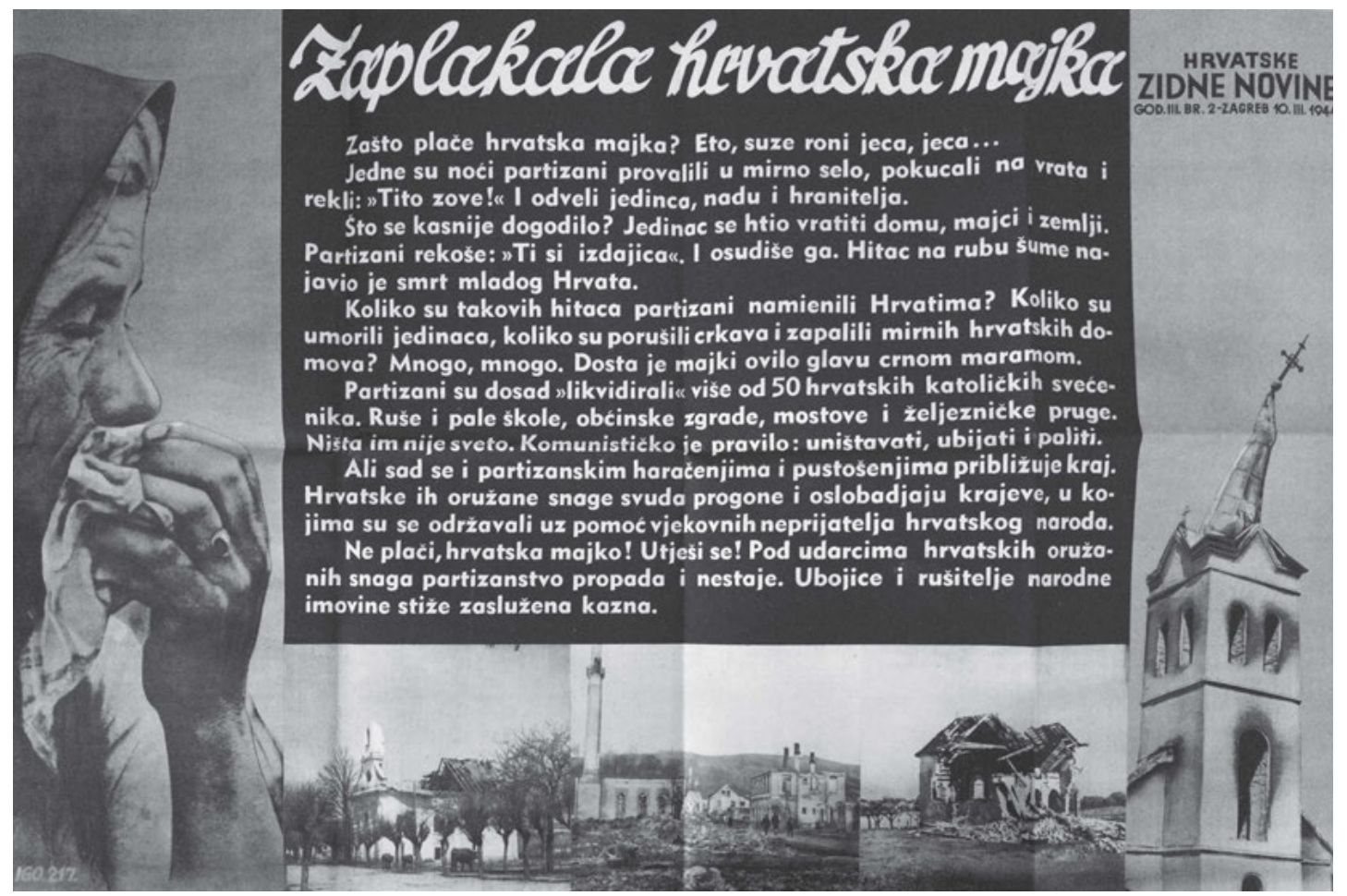

Poster with the heading 'Tears of a Croatian Mother'. Archive of Bosnia and Hercegovina, FOND NDH.

\section{Founding the New Yugoslavia's Telegraph Agency}

Telegrafska agencija nove Jugoslavije, or TANJUG for short, was founded on 5 November 1943. Its founding was an extremely important event for the Partisan movement, both for propaganda purposes and for the development of wartime photojournalism. It was founded during preparations for the Second Session of the AVNOJ in Jajce, Bosnia. At this session, the AVNOJ was recognised as a legislative body and the foundations were laid for the new Yugoslavia's federal form. The main advocate for establishing TANJUG was the painter Moša Pijade. ${ }^{35}$

Vili Šimunov-Barba took one of the first photographs of the TANJUG editorial team with his Leica. Besides him, several sources also mention Ernest Grgić, a photographer who worked as a radio-telegraphist. Grgić was one of the first to take photographs of TANJUG's audience - people listening to the radio as it broadcast news in English and Croato-Serbian. In September 1944 at the instigation of Moša Pijade, the agency succeeded in transmitting five photographic images by telegraph for the first time from the island of Vis. The wire-

35 For those interested in the founding staffers at TANJUG: Vladislav Ribnik was appointed director, Milan Gavrić and Mahmud Konjhodžić were correspondents, Veljko Dragićević, Jozo Butorac, Anđelko Gančević and Ante Runjić were radio-telegraphists, Aleksandar Tepavčević-Englez and Nikita Bakov were stenographers, Lepa Pijade, Olga Humo and Jara Ribnikar were translators, and Danilo Kabić and Vili Šimunov-Barba were photojournalists. 
photo - a picture transmitted by electrical signals via telephone wires - marked a technological turning point for TANJUG, although in some respects it was playing catch-up, as other news agencies had already adopted wire photography in the 1930s. The Soviet newspaper Komsomolskaya Pravda published some of the TANJUG photographers' works, with the result that TANJUG images featured in a foreign news magazine for the first time. ${ }^{36}$

The radio station Slobodna Jugoslavija (Free Yugoslavia) started broadcasting on 2 November 1941, initially from the town of Ufa in the Ural mountains, and later from the Comintern building in Moscow. Its director, Veljko Vlahović, ${ }^{37}$ stated that TANJUG's founding was of great importance for the development of photojournalism, too, and that the organisational prerequisites were finally in place for establishing a professional photojournalist service. Besides transmitting news by radiotelegraph, broadcasts by the AVNOJ's radio station were also planned. Also in the pipeline were photo-reportage assignments and war reporting, an exhibition, an illustrated weekly and a network of correspondents. ${ }^{38}$ Within the agency, all manner of training courses were given, such as in handling portable radio equipment, encryption, handling cameras and developing negatives. ${ }^{39}$

TANJUG's task was to represent and promote the Yugoslav Partisan movement globally This went hand in hand with the political struggle for the recognition of the People's Liberation Struggle - despite its communist and revolutionary character - as the only anti-fascist movement on the territory of Yugoslavia. Over time, the agency would evolve to become one of the most important and most professonal in this part of Europe. It collapsed during the 1990s when it fell under the control of the regime of Slobodan Milošević. In terminal decline ever since, it recently faced liquidation.

Trained professional photographers such as Stevan Benčić and Branko Savić joined TANJUG during the Second World War. Savić had trained in photography in Berlin and his father owned a photo shop in the centre of Belgrade. ${ }^{40}$ His work includes some particularly interesting photojournalist shots taken during the liberation of Jasenovac which he wit nessed along with Peko Dapčević. These photographs were stored on several dozen TANJUG negatives dating from the period 1944 to 1947. The negatives and their contact prints were believed to be subsequently stored in the Office of Marshal Josip Broz Tito and were recently discovered by the curators of the Museum of Yugoslavia in Belgrade. The present publication features some of the undeveloped photographs that the curators found on the negatives, which are published here for the first time ever. Three photographers are mentioned by name: Branko Savić, Isak Koen and Pavle Obradović. Many years after the war, Savić described the conditions he found at the camp at Jasenovac on its liberation:

36 Veseljko Huljić, Vis 1941-1945, Split 1979, p. 268.

37 Valter Roberts, Tito, Mihailović i saveznici 1941-1945, Belgrade 2013, p. 82.

38 Veseljko Huljić and Milovan Dželebdžić, Veze u Narodnooslobodilačkoj borbi 1943-1945, vol. 2, Belgrade 1984, p.145; Enver Ćemalović, Mostarski bataljon, Mostar 1986, p. 163.

39 Mihajlo Marić, 'Fragmenti iz okupiranog Beograda', in: Veze u NOB-u 1941-1945. Ratna sećanja, vol. 5, Esad Tihić and Momčilo Kalem (eds.), Belgrade 1981, p. 127. 


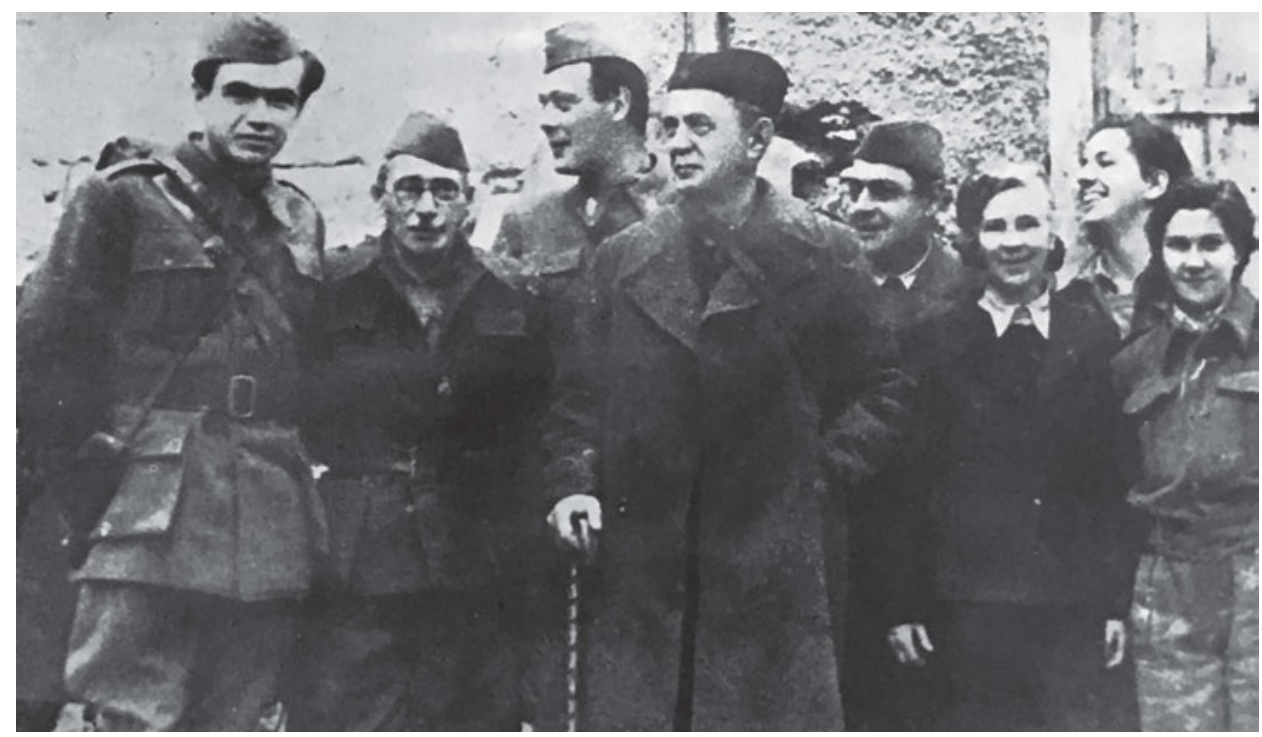

The founding TANJUG editorial staff in Jajce, with Ivo Lola Ribar (far left), Moša Pijade, Vladimir Velebit, Ivan Ribar, Vladislav Ribnikar, Lepa Pijade, Olga Humo and Jara Ribnikar (far right). Photographer nknown (Vili Šimunov-Barba?), from the book TANJUG 1943-1963, Belgrade 1963, p. 7.

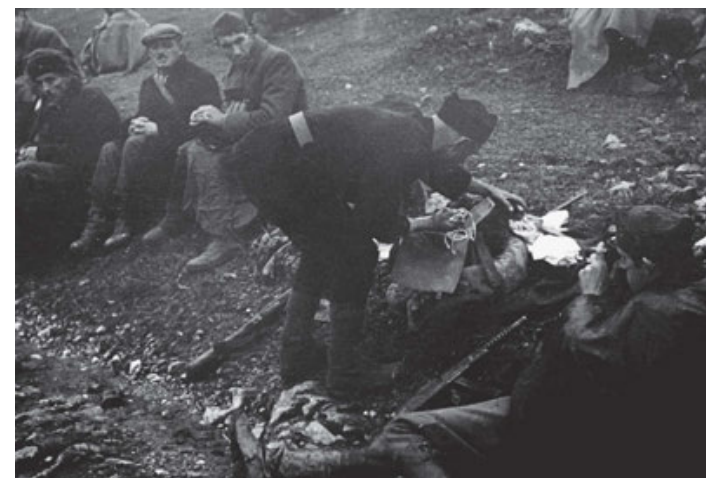

Delegates resting on the way to the Second Session of the AVNOJ, with Otmar Kreačić-Kultura (taking photo) and Dr Pavle Gregorić (centre), November 1943. Photographer unknown. Museum of Yugoslavia, III-225.

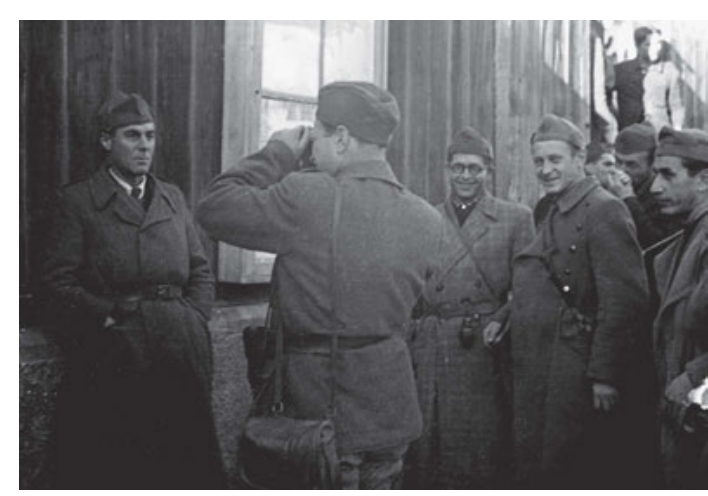

Photographer Vili Šimunov-Barba taking pictures of delegates at the Second Session of AVNOJ on the street in Jajce, November 1943. Photographer unknown. Museum of Yugoslavia, III-274.

Four of them were still alive. They were crawling along the wall of the brickyard when they heard shots approaching. They managed to save themselves. I took pictures for as long as I had enough film [...]. The waters of the river Sava retreated. There was a row of people chained up. All dead. Around fifteen to twenty of them in a line. Just when I thought everything was over, another massacre came to light. They had drowned them alive. When the water level dropped, you could see everything. ${ }^{41}$ 


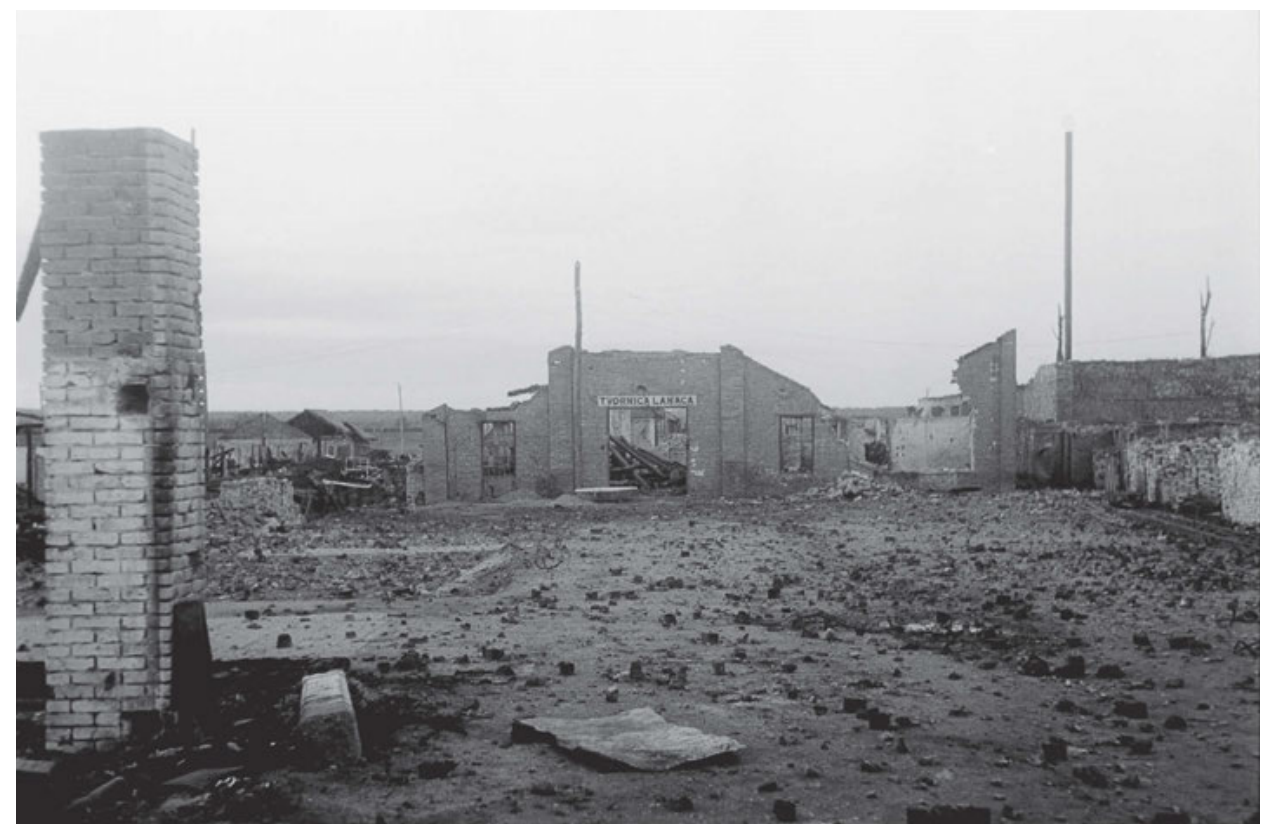

The Partisans entering Jasenovac concentration camp, deliberately destroyed by Ustashe in retreat, 5 May 1945. Photo: Branko Savić. Museum of Yugoslavia, VIS 28604.

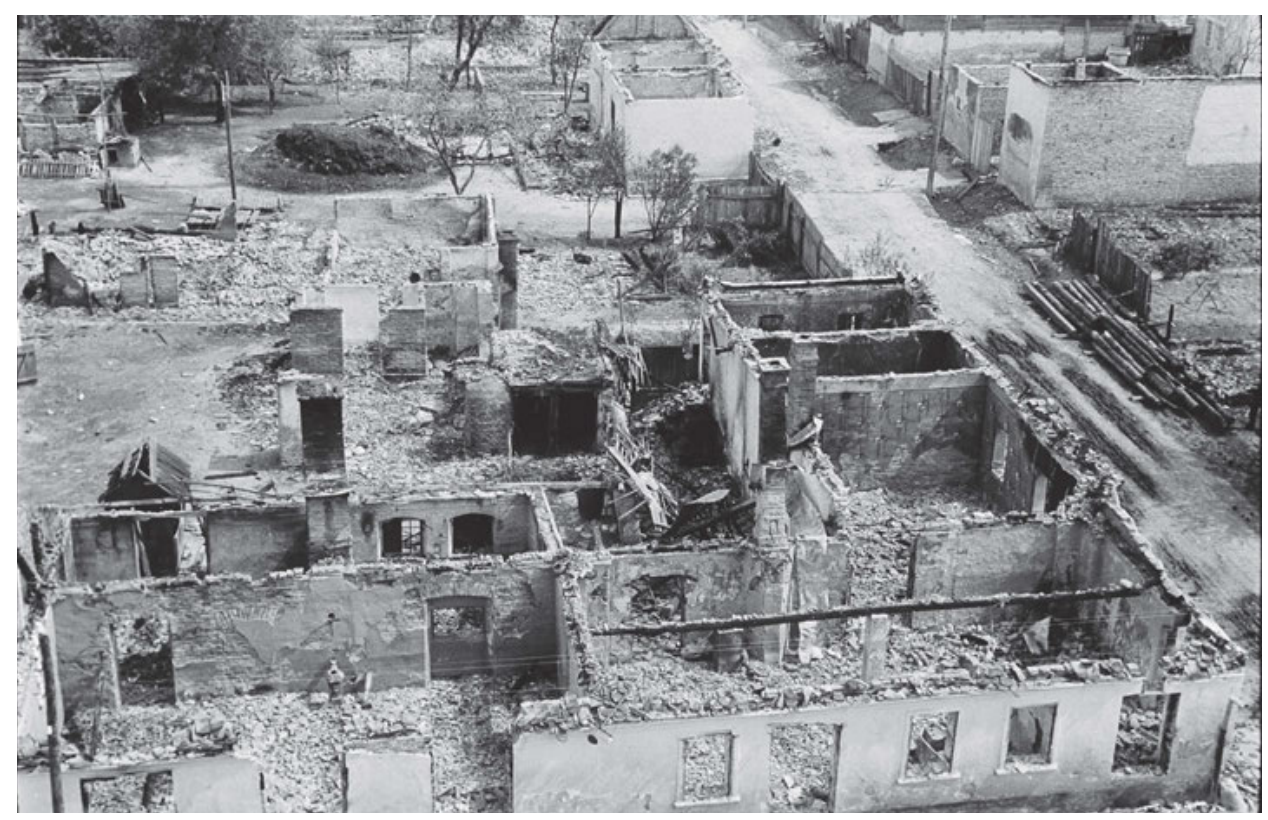

The ruins of the village of Jasenovac, as seen from the tower of the Catholic church, after the Ustashe had razed it to the ground in scorched-earth retreat. Photo: Branko Savić. Museum of Yugoslavia, VIS 28614. 


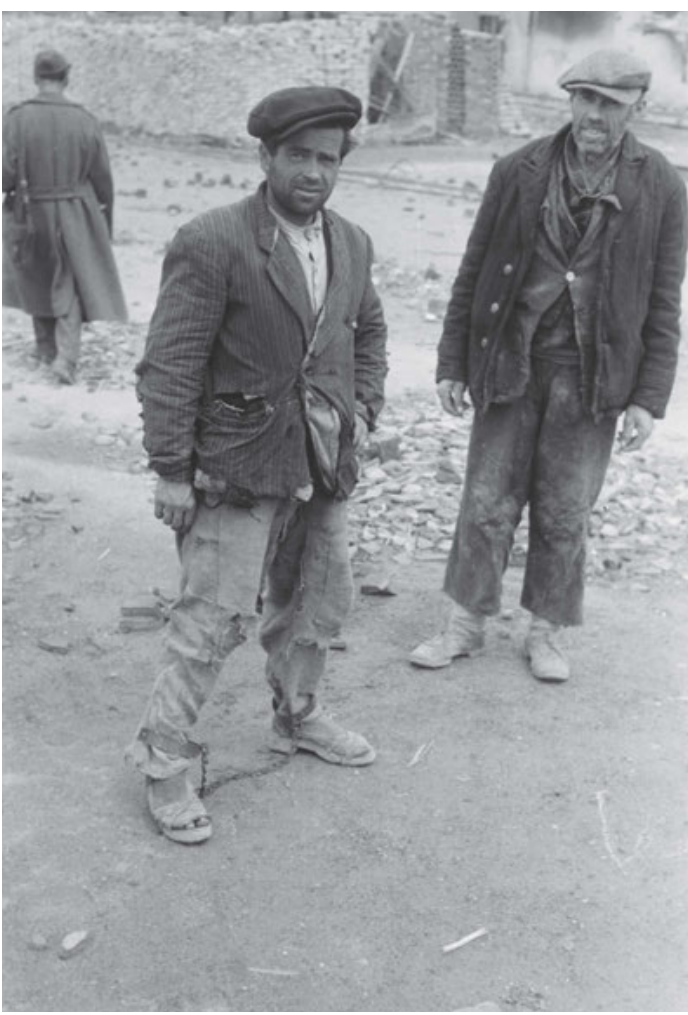

Former prisoners of Jasenovac concentration camp, image dates from same day as the previous two photographs. Museum of Yugoslavia, VIS 28621.

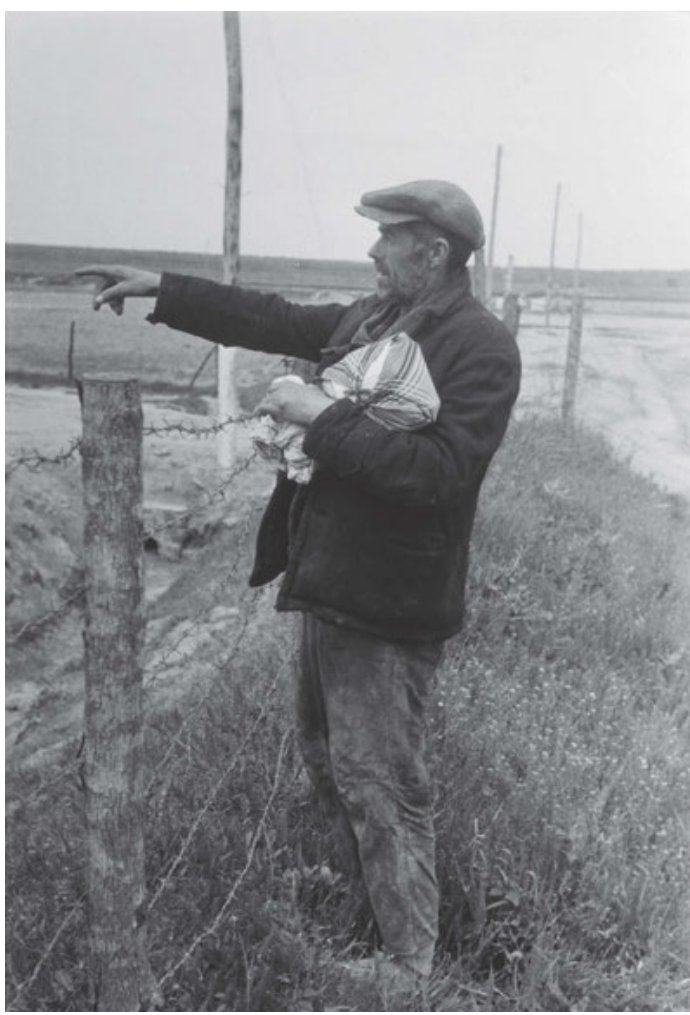

Eyewitness of the Jasenovac concentration camp, image dates from same day as previous photographs of Jasenovac. Museum of Yugoslavia, VIS 28626.

At that same moment, Mato Tačković was also on the ground taking photographs of Jasenovac concentration camp. ${ }^{42}$ He was a member of the photography unit of the Slavonia District People's Committee and entered Jasenovac with the Twenty-Eighth Slavonia Division, on 24 April 1945.

What happened to Savić's remaining negatives has not been clarified to this day, but it can be assumed that they were shot in the same period as the photographs depicted in this book. Partisan activities were strictly controlled at that time. Along with the district commissions for war crimes, corps commanders received orders to gather all data on the concentration camps and prisons in Jasenovac, Slavonski Brod, Savska Cesta, Đakovo, Slavonska Požega and Feričanci and to photograph them immediately after they had been liberated. All photos had to be delivered to the State Commission to Investigate Crimes Committed by the Occupiers and Their Collaborators. ${ }^{43}$ These photos stand out in terms of their technical and photographic quality and are certainly comparable with the

42 Đorđe Mihovilović, Jasenovac 1945-1947. Fotomonografija Jasenovac 2016, p. 18.

43 Zbornik dokumenata i podataka o narodnooslobodilačkom ratu jugoslovenskih naroda, vol. V/34: Borbe u Hrvatskoj 1944.

godine, Belgrade 1966. 


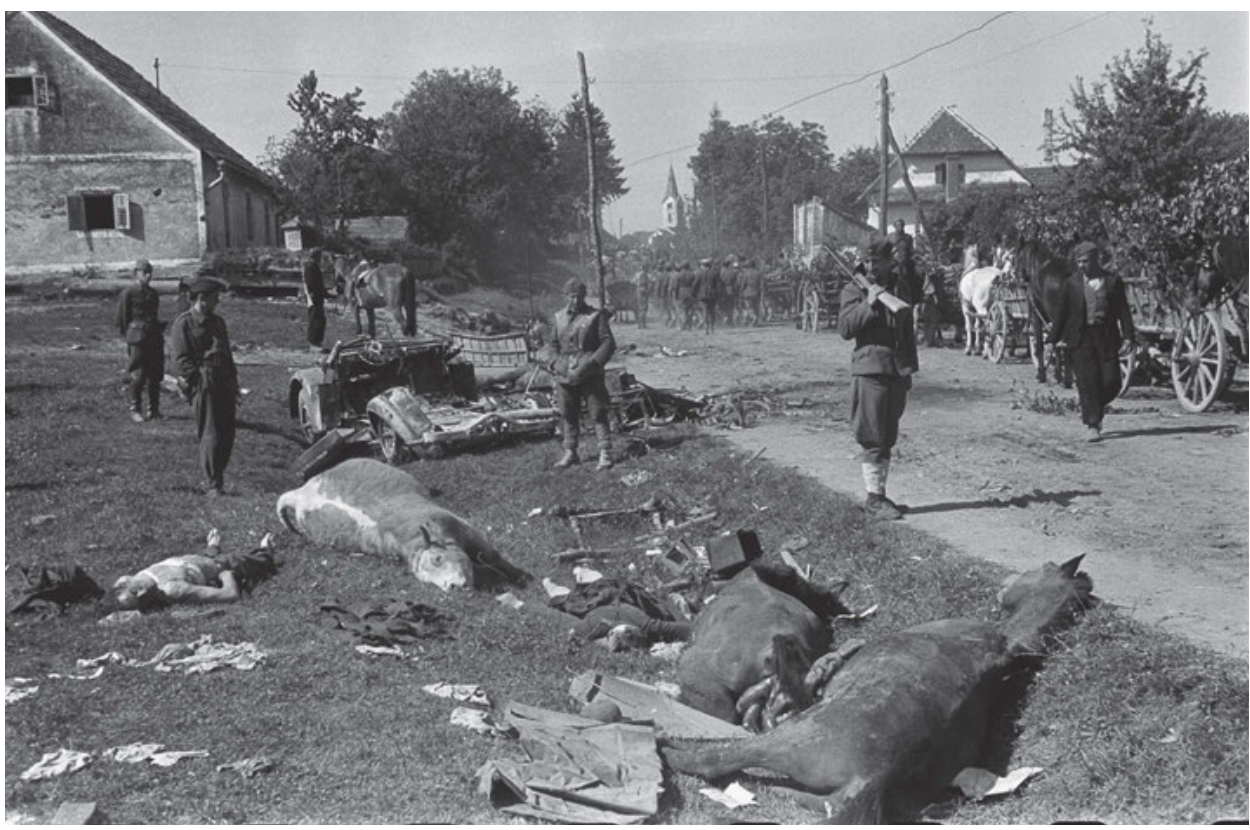

Yugoslav Army advancing on Zagreb, May 1945. Photographer unknown. Museum of Yugoslavia, VIS 2870.

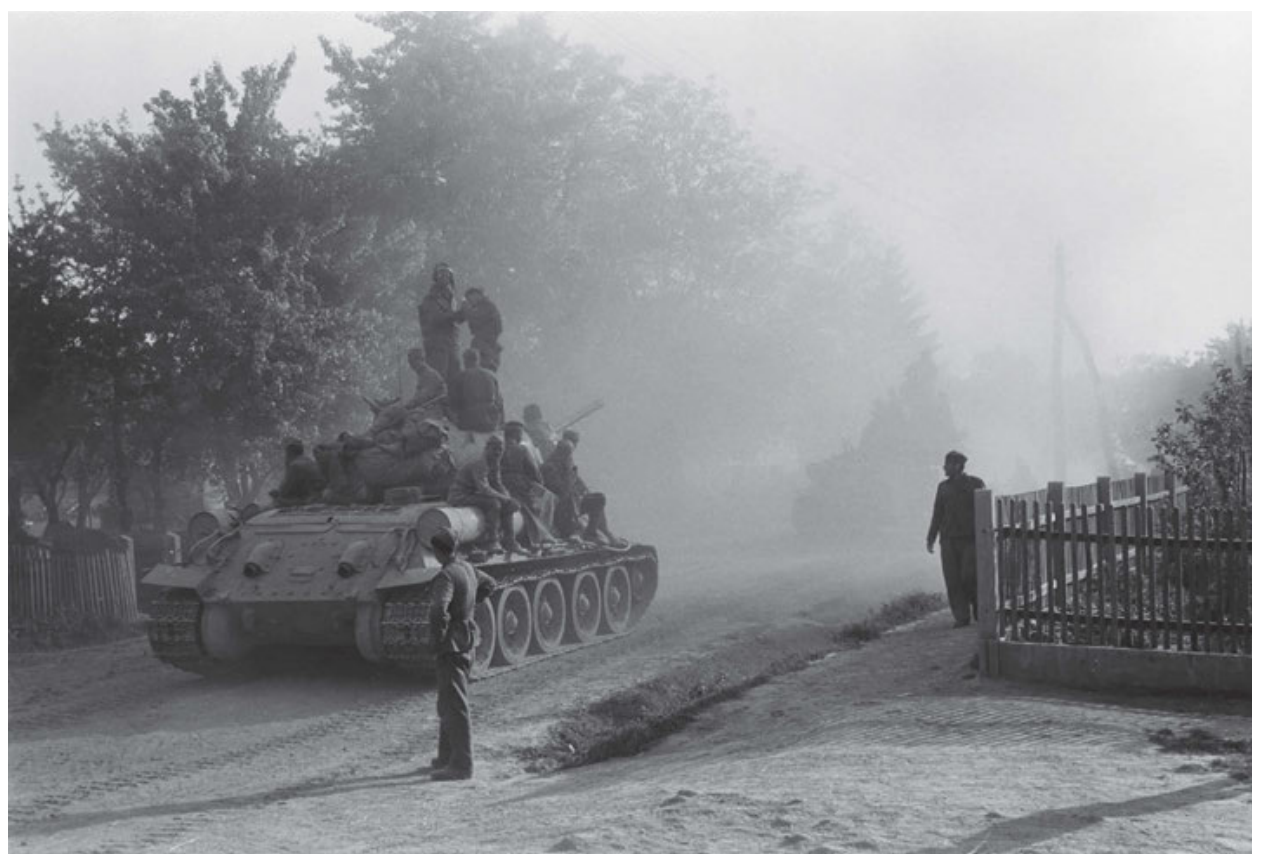

Yugoslav Army advancing on Zagreb, May 1945. Photographer unknown. Museum of Yugoslavia, VIS 28819. 


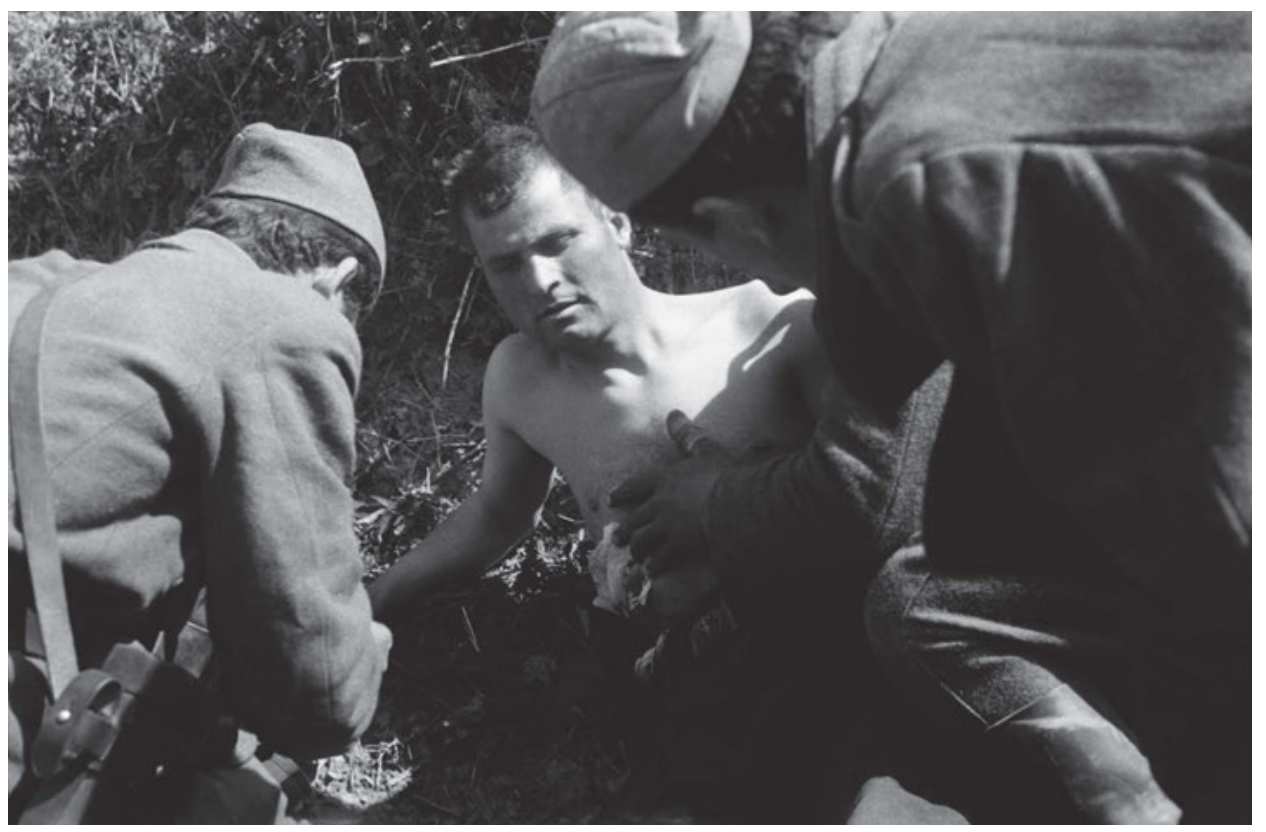

Wounded Partisan during push to take Zagreb, May 1945. Photographer unknown. Museum of Yugoslavia, VIS 2890.

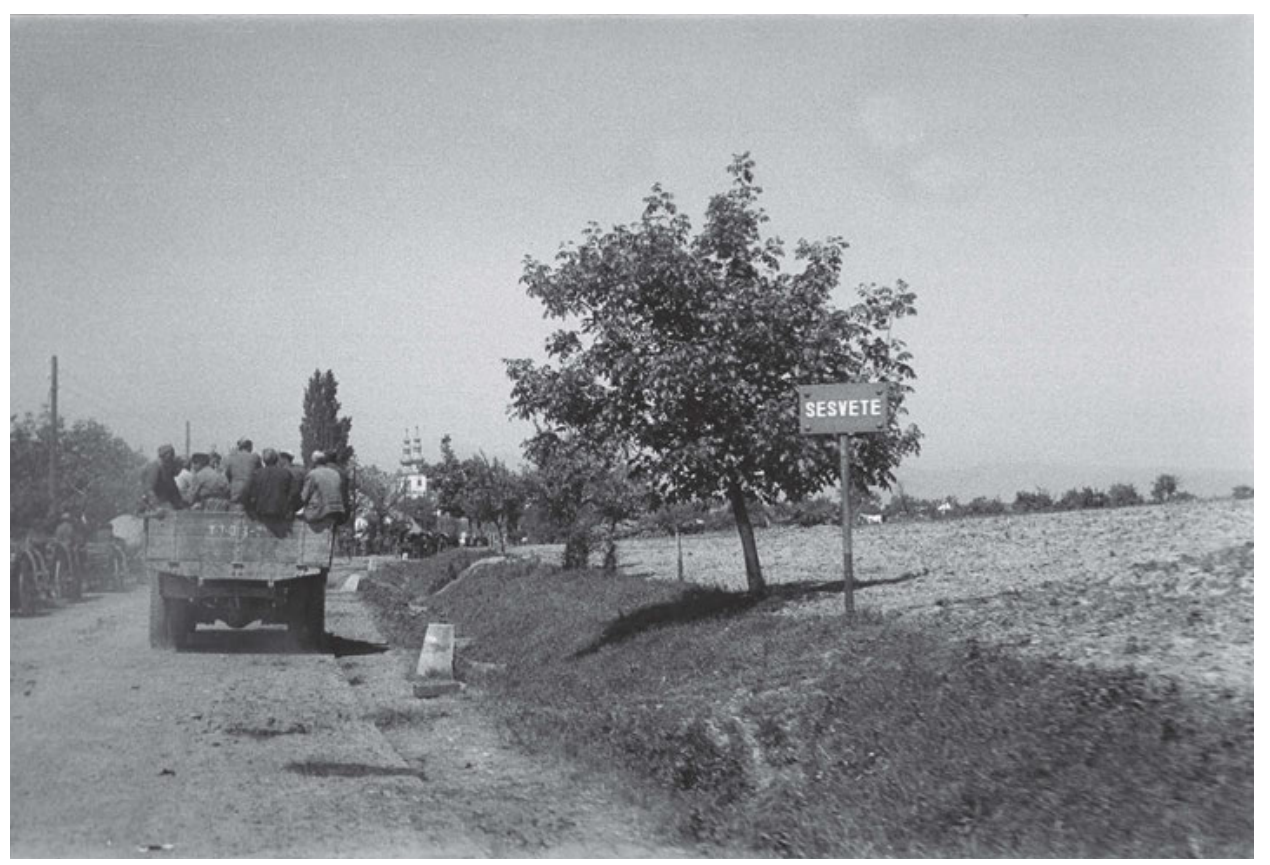

The Yugoslav Army advancing on Zagreb, May 1945. Photographer unknown. Museum of Yugoslavia, VIS 28922. 


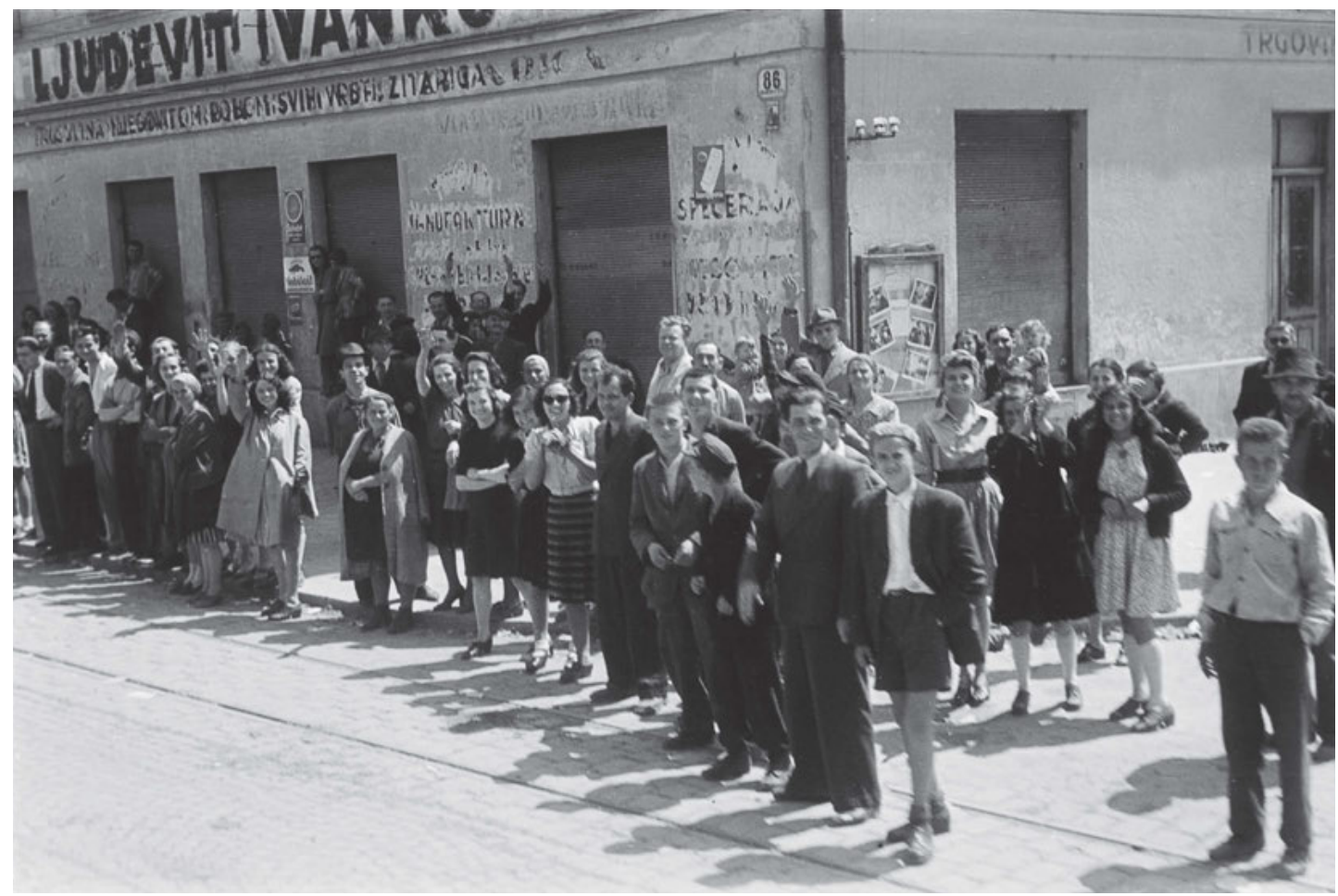

Civilians greeting the Yugoslav Army entering Zagreb, 8 May 1945. Photographer unknown. Museum of Yugoslavia, VIS 29012.

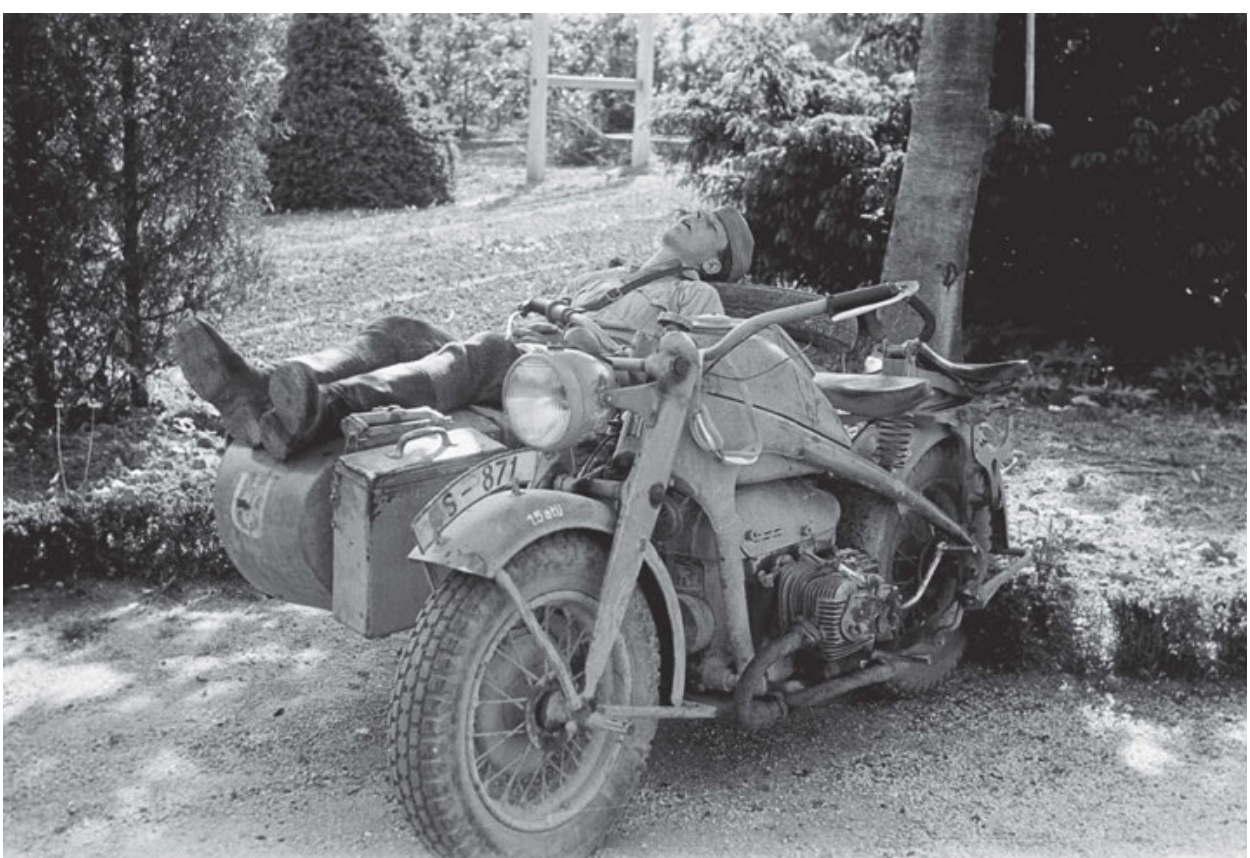

During push to take Zagreb, 8 May 1945. Photographer unknown. Museum of Yugoslavia, VIS 29123. 


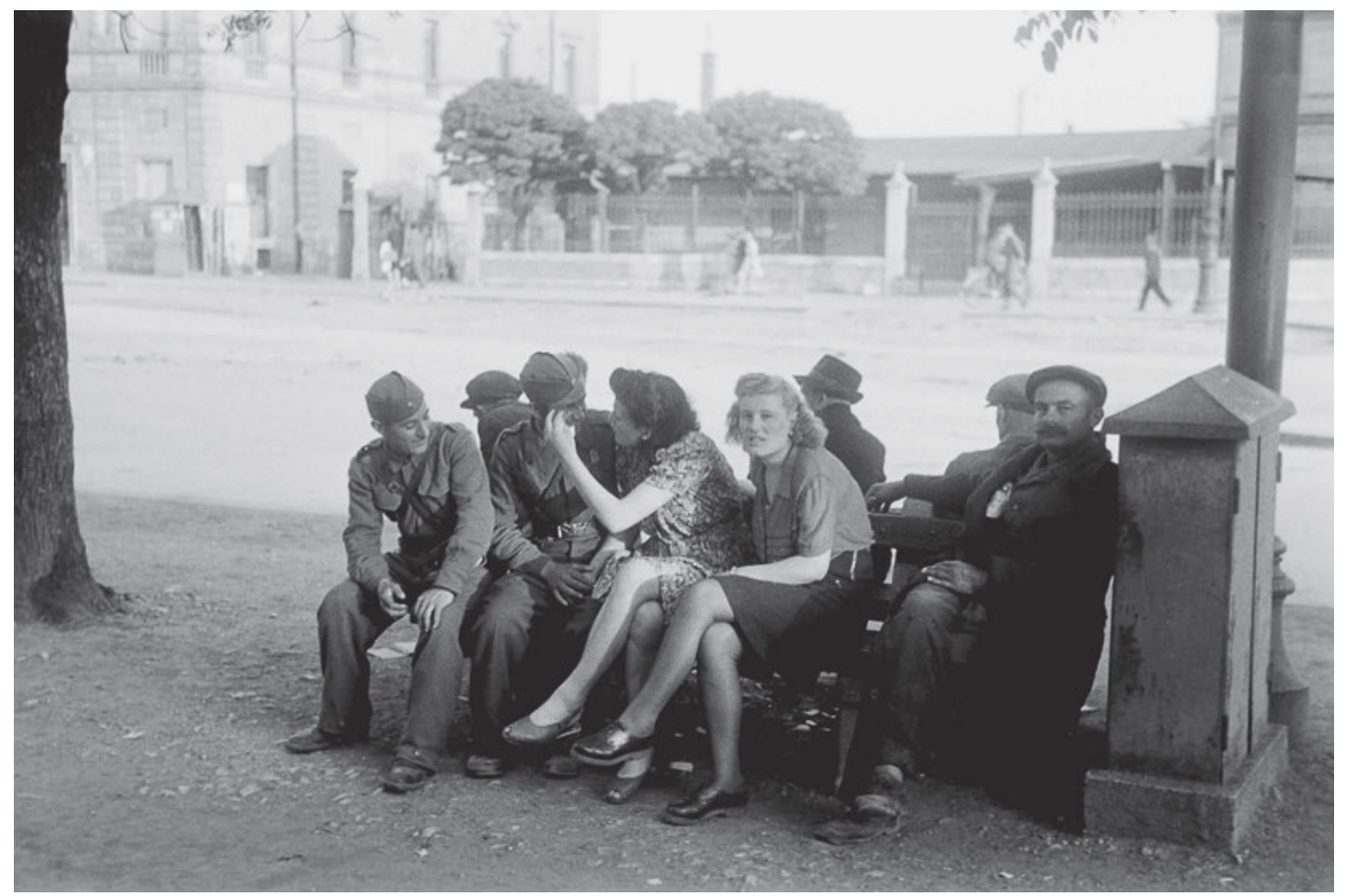

The Yugoslav Army entering Zagreb, 8 May 1945. Photographer unknown. Museum of Yugoslavia, VIS 29135.

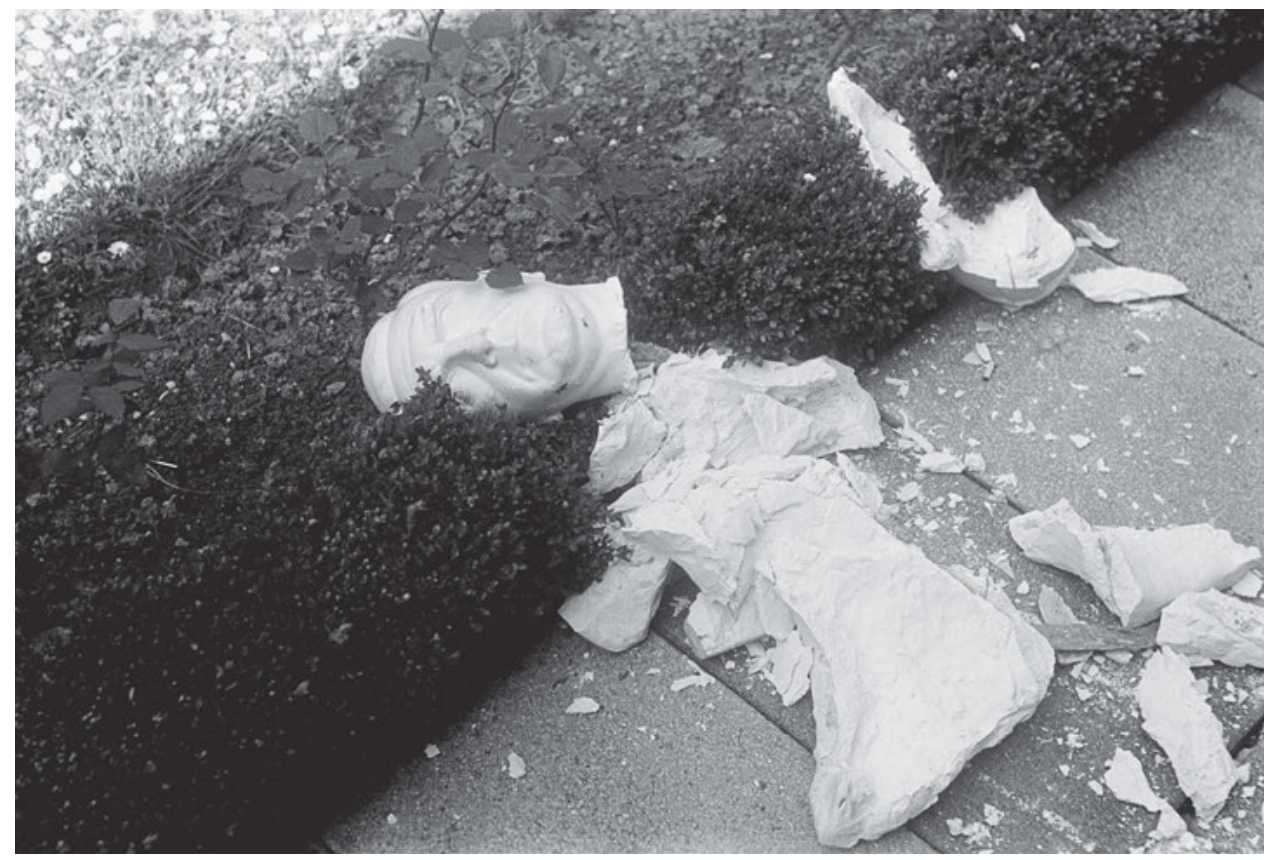

Toppled statue of Ante Pavelić in Zagreb, directly after the liberation, May 1945. Photographer unknown. Museum of Yugoslavia, VIS 29335. 


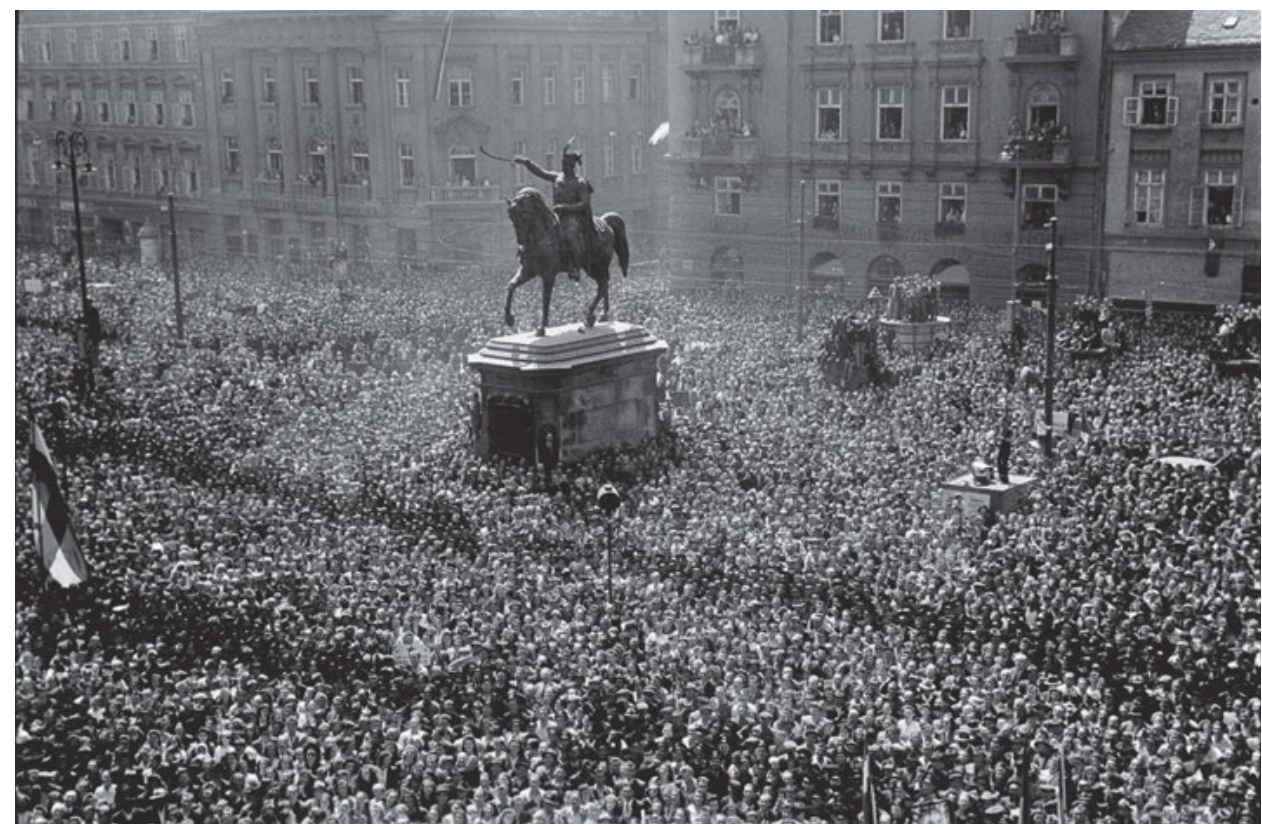

Crowds gather in Zagreb to mark the liberation of the country and the end of the war, 11 May 1945. Photographer unknown. Museum of Yugoslavia, VIS 29213.

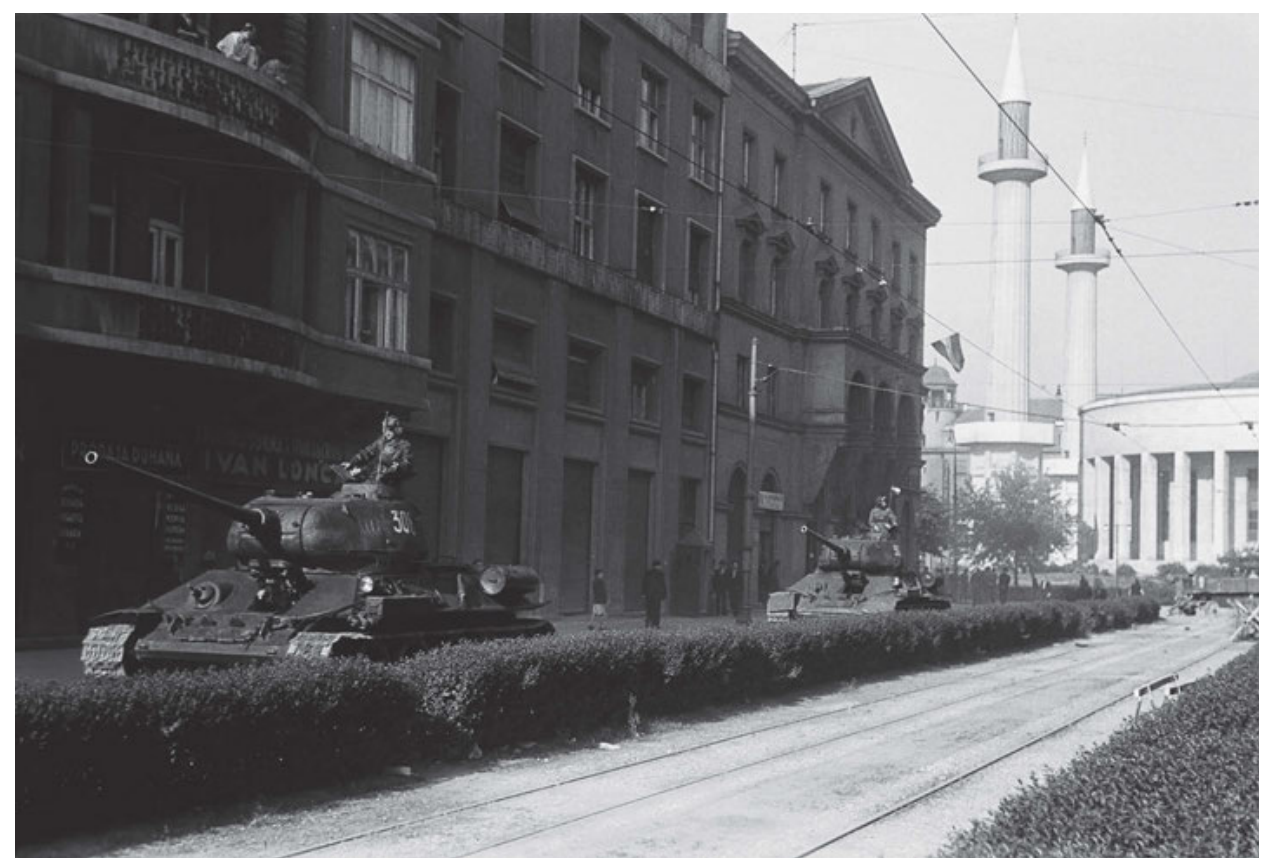

A military parade by the Yugoslav Army in liberated Zagreb, 13 May 1945. Photographer unknown. Museum of Yugoslavia, VIS 29612. 


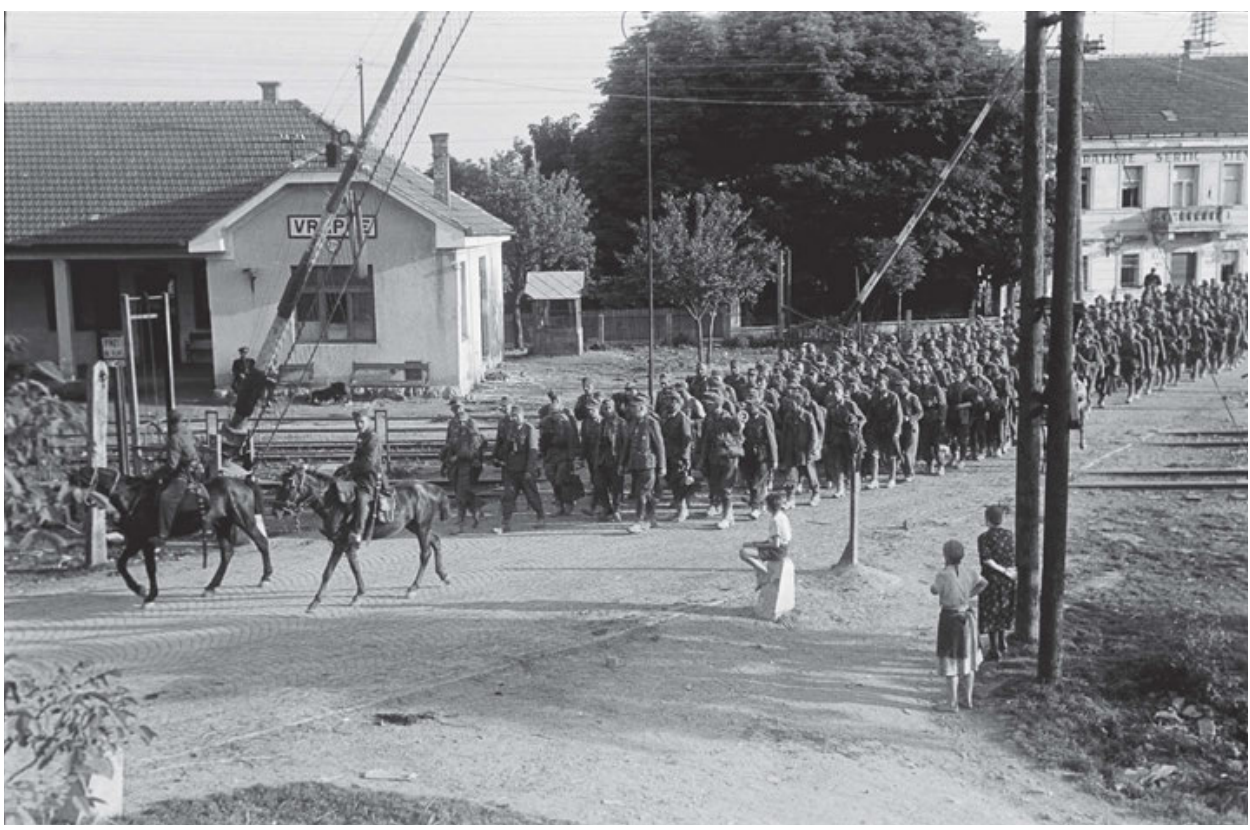

Defeated enemy soldiers captured in Zagreb, May 1945. Photographer unknown. Museum of Yugoslavia, VIS 29424.

professionalism of Allied photographers' documentary work. The high photojournalistic quality is also visible in the photographs of the liberation of Zagreb, also published for the first time in this book.

\section{On Propaganda's Impossibilities}

Despite many orders and the establishing of a propaganda apparatus, photography remained beyond centralised control. Many photographers continued to develop their films privately, without supervision from propaganda departments. Even the officials in the propaganda departments themselves often left the decisions up to the photographers. Most reports acknowledge the success of photographic work, but poor technical production and material scarcity were also constantly mentioned as limiting factors, as was the lack of trained photographers. Guided by their own intuition and creative vision, photographers took pictures of subjects they considered important. But one consistent complaint from the propaganda departments was the persistent lack of combat photography, even in the final year of the war, as demonstrated in this report by the Ninth Corps: 
We lack materials for negatives and positives, and we especially lack skilled photojournalists and photographic technicians. The number of combat photographs lags too far behind the number of everyday photographs. There are still too few daring photographs. The photography unit is thus overburdened with its current work and is not in a position to reproduce old shots in large numbers. ${ }^{44}$

The Ninth Corps received criticism that film stock was not getting to the units on time and that the film rolls that did arrive had sometimes been mistakenly used already. The instructions of the department of political education of the Twenty-Sixth Assault Division, dated 4 April 1945, and sent to the departments of political education of the brigades subordinate to it, came to the critical appraisal that precious film stock had been used up depicting unidentified columns, portraits or shots of leading military figures:

To this day, not a single brigade has sent a shot, article or biography of a prominent fighter or leader, fallen in battle, or even alive. [...] We need to stop thinking that the photographer is exclusively on hand for the brigades. This is not of significance for the brigade alone, but for our entire army! When the film stock has been developed, those pictures of value will be used for our
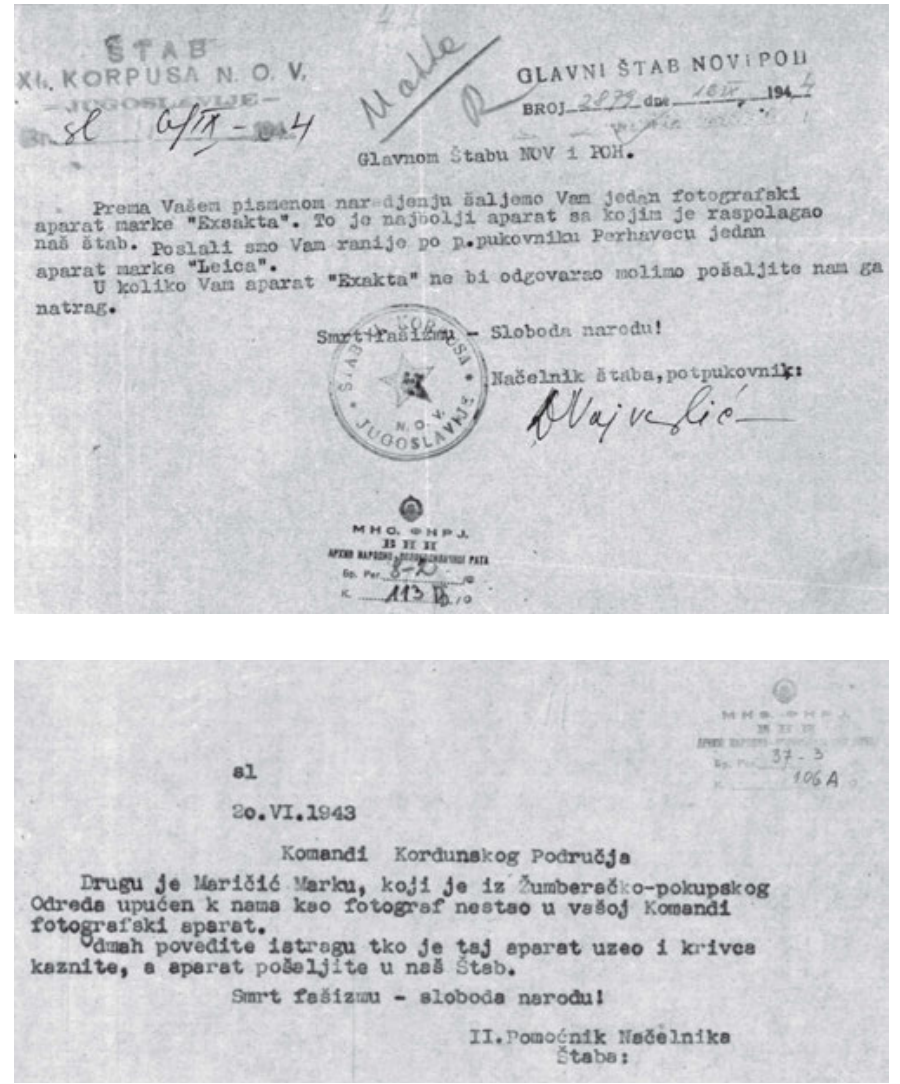

"In line with your written order, we have sent you one Exakta camera. It is the best camera that my headquarters has available. Earlier we sent a Leica camera to lieutenant colonel [illegible].

If the Exakta camera does not suit you, please return it. Death to Fascism, Freedom to the People." Military Archive Belgrade, NOVJ K113B F2 8.

"To the Kordun region command, Comrade Maričić Marko from the Žumberak-Pokupsko division, directed to work with us as a photographer, lost his camera under your command.

Carry out an investigation immediately into who took the camera and punish the guilty party, and send the camera to our headquarters." Military Archive Belgrade, NOVJ K113B F2 8. 
IITAБ VII ВОЈВОВАНСКЕ БРИГАДЕ

Народно-ОС Мобо ди мачкө во јскө

Jy rocata ви je

Бро ј: Саушбено

Дане 4-XI-1944 год.

Половај
П口егис

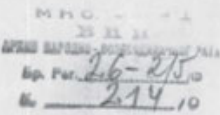

\section{Друже Чамо,}

Фото-репортөр нане Бригаде Лаза, невнем. му презиме, већ неко ико дана се нө јевле овок штебу, што нас је нагнело де ге сотрекимо. Јучө

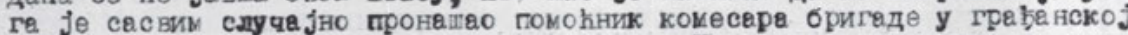
куки у соби аяменика коментанданте мөста. На питавө овога шта он ту ради он јө дао овако сияшан одговор. Ја сам друже кокесяру на боловану, добио сам дужност көо први помоһник коменданте кеста. 0 свеку овокө

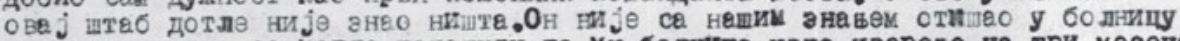
и неянако како се могло догодити да му болница ияда уверевө на три месеца болозана. Кад он уопштө није болестан. А како се додворио у команду мөста

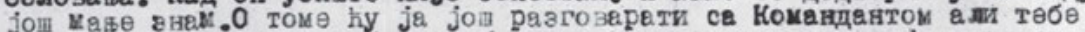
обивөлтевек внева ради јер он јө сада прөстео вршити сво ју дужност, соторөпортөрн, па га ти пронађи и одуәии ку апарат.

Пази ти тог шпекуланте, како сидок жели постати нөки грађански уцравник. ОН је како чујем пришио поручничке анаке.Нвзнак ко му је тө внаке део и да ди он неквд био поручник. Одмех иу реди да скине анакә пошто ја неңу имати эремена де будек са вим. Иодим тө учни крај са глупостиме ко ја чини тај човек. Да аи су готовө саике ко јө си скикиоонеј дан?

Сирт фашиаку - Сдободе нероду!

\section{$\left(u_{\bullet} n_{\bullet}\right)$}

С другарским поадравок Комесар VII војво јанскө бригедө. дазар цубинковй C.P.

Да јө овеј прөпис веран своме оригинаду који се налази код

Прспегендног отсеке ГтВ, тврди: Пропегандни отсек Гші

Нови Сед, 10 новекбра -1944 год. Cхрг сешивку - Сдободе народу!

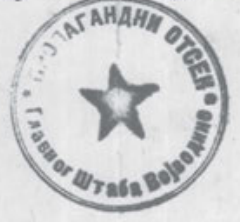

Mөф пропагандног отсөка:

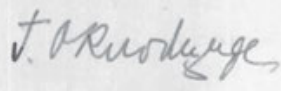

Message about a photographer with the Seventh Vojvodina Brigade reporting in sick, requesting to confiscate his camera. Military Archive Belgrade, NOVJ K214 F5 26.

central propaganda service: for the army, divisions and the brigades, so that the brigades can put on an exhibition tracing their history and so on. Shots of no great significance will be returned to you for archive purposes as originals with the negatives, while the more important shots will be returned in the $13 \times 18$ format. Pointless shooting that uses up material is forbidden in the brigades. You can only take pictures if you have an important propaganda goal, e.g., shots that interpret our struggle, important political and cultural moments, as well as upbeat encounters with the people being liberated etc..$^{45}$

A report on the work of the photography and film section in the Fifth Serbian People's Liberation Assault Brigade relates the position of photographers in certain military units: 
The section had three members, and in late February 1945, a further two photographers arrived. Due to a lack of expertise, a massive amount of photographic material was ruined at the hands of these photographers, and the head of the propaganda department reported the following: 'We can say that soon we will have more damaged than usable photographs. In most cases, the shots are blurred and show little artistry, i.e., were taken without any journalistic skill. Over this period, 154 different images were shot, of which 139 were a success, but not great, while 15 were a complete failure. Apart from that, much was left undeveloped on the films as it seemed that the photojournalists had not got to grips with the basic concepts of photography. In the brigade we do not have any better photojournalists and we must, of course, place stricter checks on their work and make do with them for the time being.'46

This particular brigade, the Fifth Serbian Assault Brigade, nevertheless managed to organise seven exhibitions that included, in total, eighteen photographs from combat positions, sixteen pictures of meetings of the engineer battalion, twenty-three photographs covering the celebrations of the Red Army's anniversary, and sixteen on brigade manoeuvres. As in the other brigades, photographs from the front lines and of direct combat were lacking. There were also rare cases in which certain photographers were punished for acts of cowardice and even treason before the enemy. Yet most often the problem lay in neglect. ${ }^{47}$ The war photography unit of the Twenty-First Serbian Assault Brigade also had issues with individual photographers' personal conduct:

They drew special attention to their cameras, often hanging around outside the headquarters and photographing officers. The brigade's political commissar, Mirko Jovanović, did not like their milling around the headquarters and really wanted to see them in the line of fire, photographing fighters waiting in position, charging and repelling attacks. ${ }^{48}$

Instead of issuing strict orders to them, the political commissar managed to convince and motivate them to travel to the front line, and within ten days they managed to organise an exhibition that turned out to be a great success:

The arrival of photojournalists on the front line of combat, in the trenches and dug-outs, aroused a lively interest and curiosity among the fighters and leaders. In some places the fighters scorned them and made jokes. The photojournalists did not have time to respond to those who scorned them and just continued photographing. As luck would have it, some photojournalists even found themselves in the midst of the first exchange of fire and had their baptism of fire and shot pictures of historical value. ${ }^{49}$

46 'Izveštaj Propagandnog odsjeka 5. brigade od 15. ožujka 1945. godine o radu kulturno- prosvjetne sekcije od 15. veljače do

15. ožujka 1945. godine', in: Peta srpska NOU brigada, Stanimir Jovanović and Dragoljub Mirčetić (eds.), Belgrade 1989, p. 289.

47 People's Liberation Army of Yugoslavia, Military Archive Belgrade, K60B F5 22.

48 Milorad Gončin, U rovovima Srema, Belgrade 1981, p. 210.

49 Ibid. 
The correspondence that the Supreme Command's propaganda department sent to the staff of the Fifth Corps on 1 December 1944 discussed the extent to which material and technical conditions influenced the organising of propaganda activities. In it, they requested that all Leica cameras 'found on persons and in use for personal satisfaction' be surrendered to them. ${ }^{50}$ From the same document we also learn that the photography unit of the Supreme Command did not have a single good-quality camera available to use. This is why the staffs of the corps spent so much time searching for photography equipment..$^{51}$
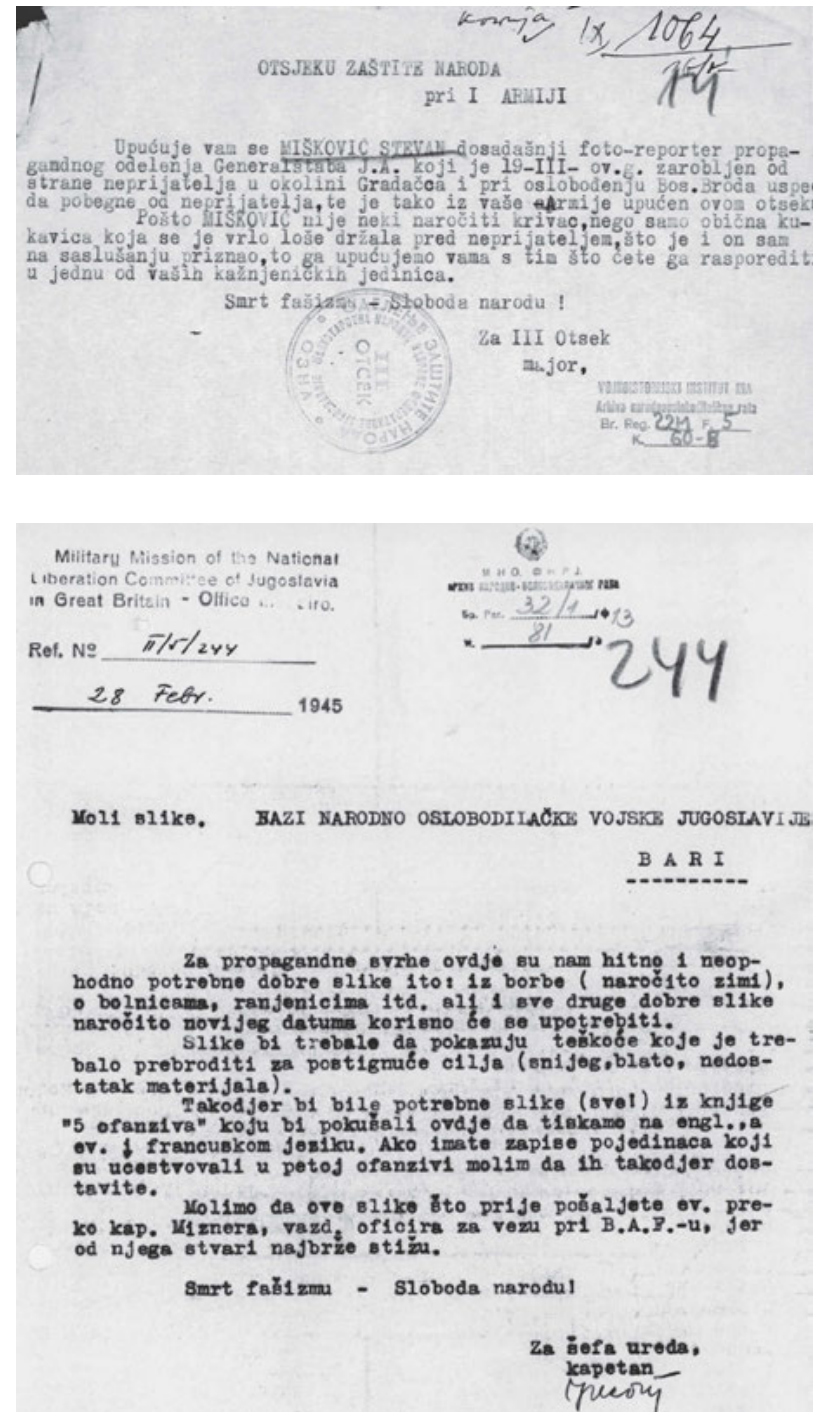

Report from General Staff of People's Liberation Army concerning the capture of a Partisan photographer by the enemy, his conduct while in custody and subsequent escape. Due to his 'cowardly manner' in enemy hands, the photographer is to be sent to a special department for punishment. Military Archive Belgrade, K60B F5 22.
Request from Allied base in Bari asking the People's Liberation Army to supply pictures for propaganda purposes, especially of hurdles (shortages, snow, mud) that have been overcome in the push for victory, as well as images from a book on the Fifth Offensive that can be reproduced in a foreignlanguage edition for English- and French-speaking readers. Military Archive Belgrade, K113B F2 8. 
Interestingly, in early 1944, the propaganda section of the General Staff of Slovenia and the Slovene People's Liberation Committee separated their war photography unit from their civilian photography service. Photographers in uniform and in active military duty were generally tasked with documenting war operations. These photographers were constantly on the move and in direct combat with the enemy. Another subset of the unit was tasked with taking pictures of liberated territory. The most frequent subjects included the consequences of enemy devastation and the destruction of civilian and commercial facilities. According to the Rules on the Operation of Photography Units, they had to send

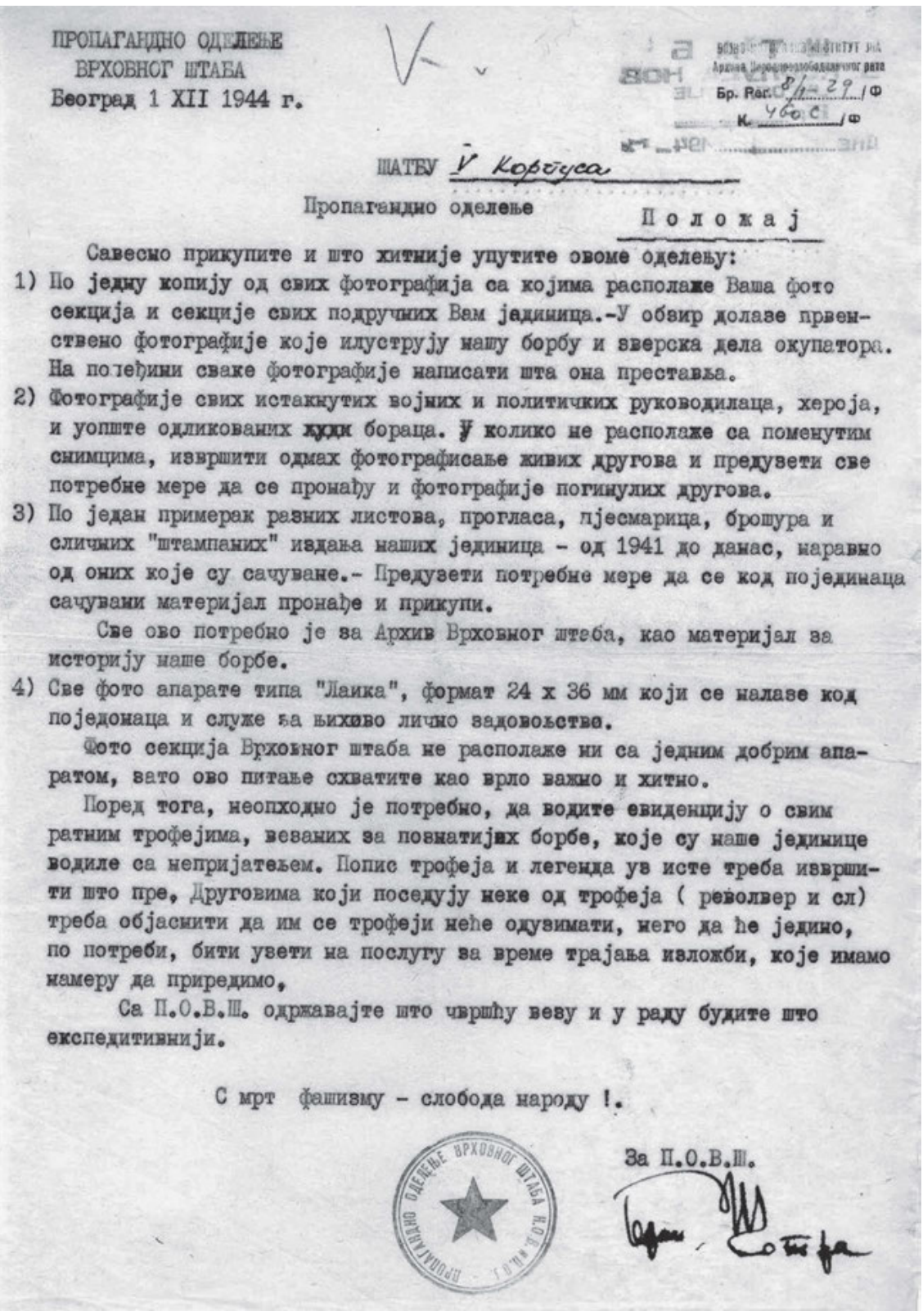

Letter from the Propaganda Department of the General Staff instructing recipient to send urgently needed photographic supplies and Leicas. Military Archive Belgrade, NOVJ K113B F2 8. 
negatives directly to the General Staff so as to create a central photo archive. ${ }^{52}$ According to various estimates, around 150 photographers were active in the Slovenian Partisan movement.

A report issued on 1 May 1945 by the propaganda department of the General Staff of the People's Liberation Army and the Partisan Detachment of Slovenia, addressed to the propaganda department of the Supreme Command, states that the units sent fifteen copies of the exhibition Sahrana generallajtanta Franca Rožmana-Staneta (The Burial of the General Lieutenant Franc Rožman-Stane) mounted on canvas with appropriate captions provided..$^{53}$ During this same period, an exhibition was held on successful sabotage actions, entitled Rušimo komunikacije (We Are Destroying Communications). Later, there was an exhibition on the Twenty-Fourth Italian Division named Fontanot, and another entitled Pohod XIV. Divizije (March of the XIV Division) that included photographs by Jože Petek. However, materials were lacking for the exhibition, especially photographic paper for blow-ups. ${ }^{54}$ The crisis of scarcity continued and a report by the same propaganda department dated 1 February 1945 mentions the shortage of photography supplies. Nevertheless, the work of the Slovenian photography unit was particularly lively and in Črnomelj, a town in southeast Slovenia, from 14 January to 24 January that year, an exhibition of the Fourteenth Division went on view, while the General Staff of the People's Liberation Army and Partisan Detachment of Slovenia compiled a photo album with all the images gathered from the unit, which was later sent to Supreme Command. ${ }^{55}$ The report from the following month states that the unit had survived the supply crisis and that a photography workshop had included 4,023 shots of various sizes that included scenes of combat, work and civilian life. ${ }^{56}$ The Twenty-Sixth Assault Division held an exhibition in Tržič (in northern Slovenia), with captions translated into Italian and English. The exhibition was accompanied by a mobile library. Two-hundred photographs - in the formats of $16 \times 24,18 \times 24,26 \times 38$ and $13 \times 18 \mathrm{~cm}$ - were pasted onto fifteen cardboard panels.

Trained amateur photographers participated in the work of Partisan photography units right to the end of the war, as evidenced in the report of the Operations Staff of Istria, dated 23 April 1944. As concerns opportunities in the field, the report says:

Cultural and educational work is not organised in a planned manner but is rather implemented ad-hoc. [...] We intend to establish a photography unit. We already have a workshop for producing, duplicating and developing photos. The squadrons have their own amateur photographers. We need one good photographer for our staff. ${ }^{57}$

\footnotetext{
52 Franc Fabec, 'Photography During the Slovene National Liberation Struggle', in: Resistance, Suffering, Hope: The Slovene Partisan Movement 1941-1945, Jože Pirjevec and Bože Repe, Ljubljana/Trieste 2008, pp. 97-99.

53 Zbornik dokumenata, vol. IX/3: Partijsko-politička dokumenta.

54 Ibid.

55 Ibid.

56 Ibid.

57 Zbornik dokumenata i podataka o narodno-oslobodilačkom ratu jugoslovenskih naroda, vol. V/26: Borbe u Hrvatskoj 1944.

godine, Belgrade 1961.
} 


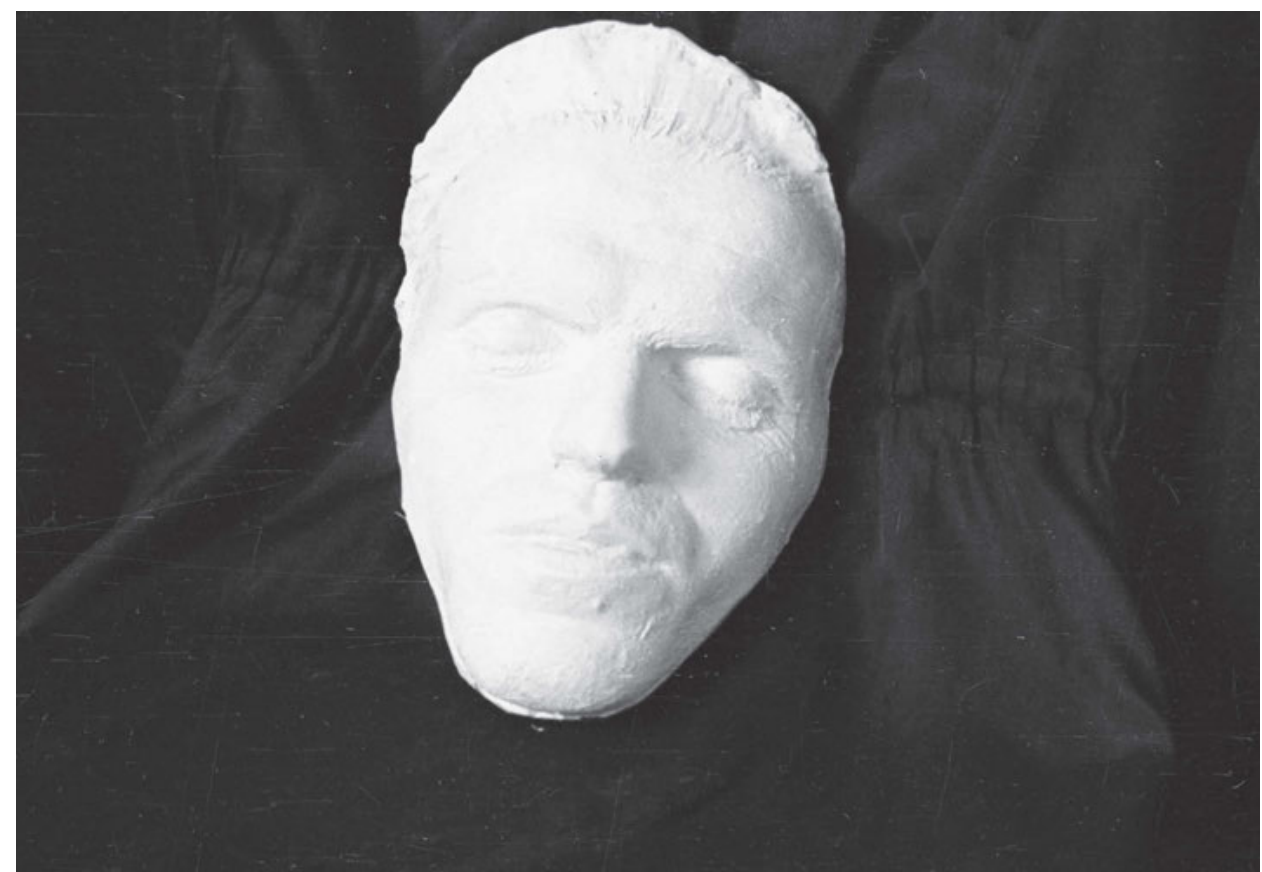

Franc Rozman's ('Commander Stane's') death mask, Črnomelj, 8 November 1944. Photo: Peter Jelič. National Museum of Contemporary History (Slovenia), TN440/16.

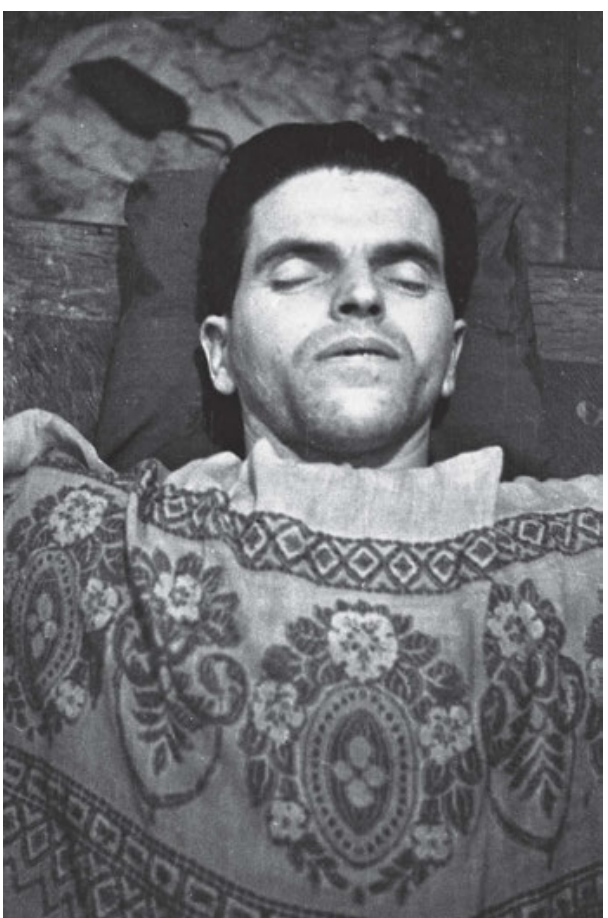

The late Franc Rozman ('Commander Stane') on a bier, Črnomelj, 8 November 1944. Photo: Peter Jelič. National Museum of Contemporary History (Slovenia), TN440/16.

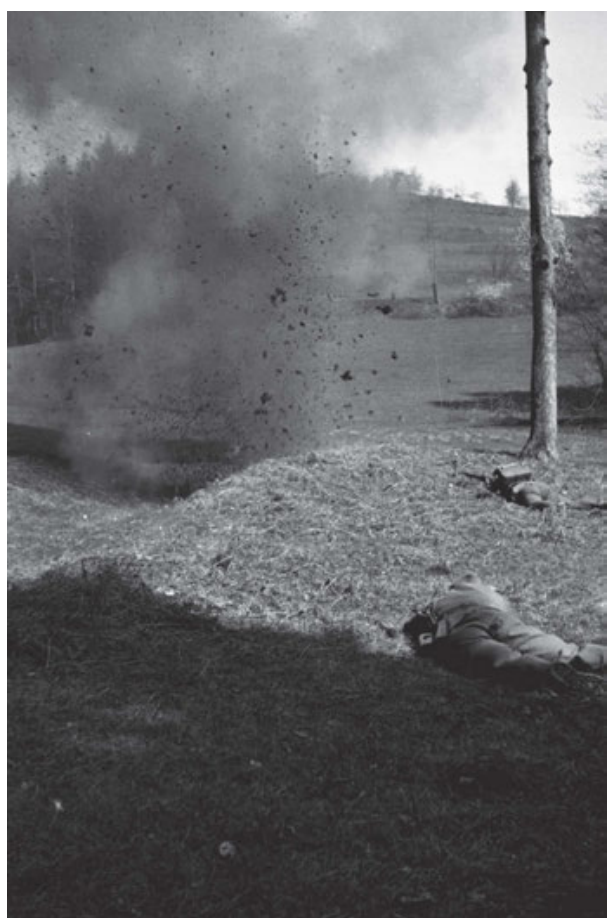

Grenade explosion, August 1943. Photographer unknown. National Museum of Contemporary History (Slovenia), TN27/40. 


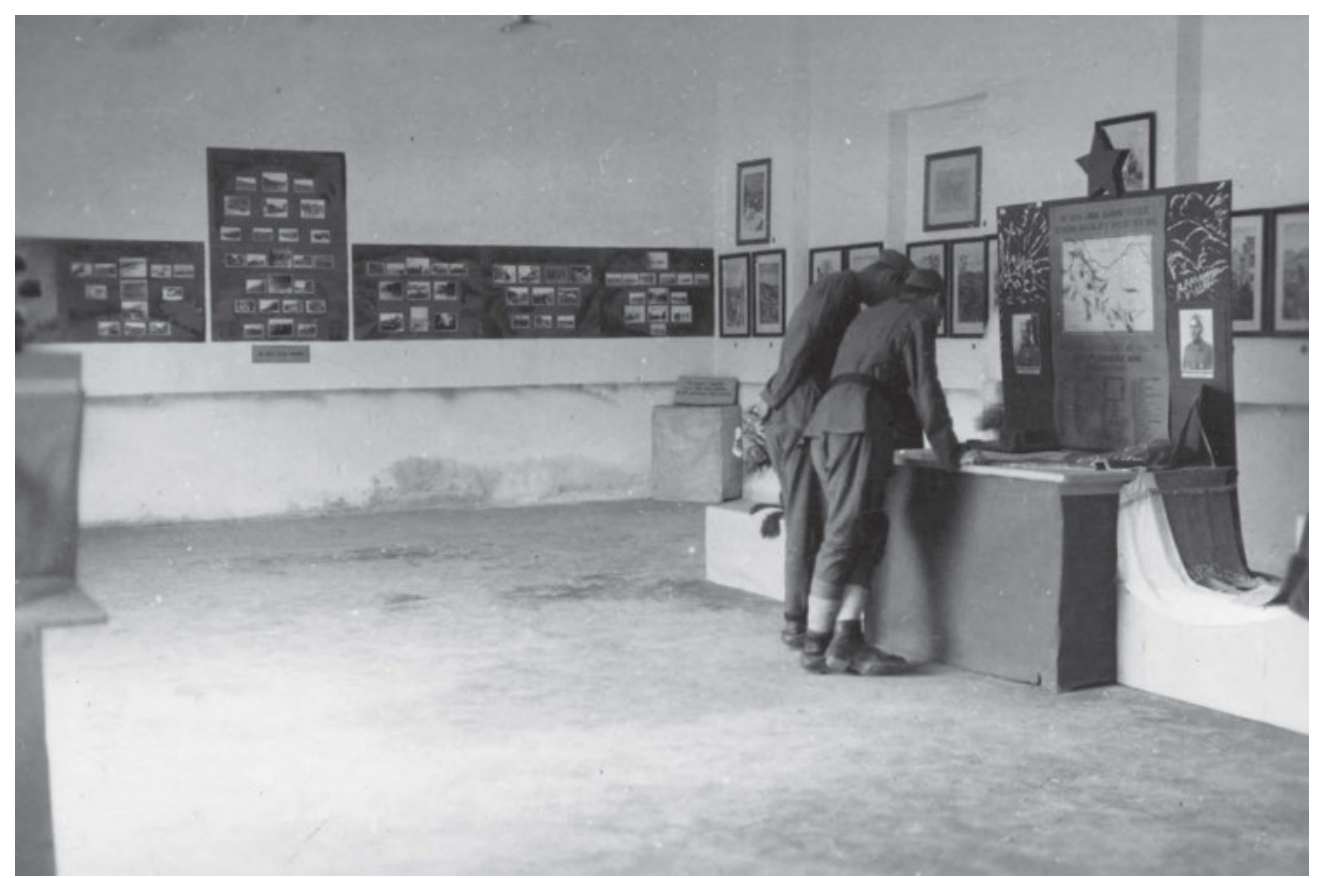

Exhibition in Samobor, 6 June 1945. Photo: Vlado Potočnjak. Croatian History Museum, HPM/MRNH-F-9155.

In recent years, other authors have covered the topic of Partisan art from 1941 to 1945. They have analysed the archives available today in detail and the many works by Partisan artists. Partisan art is difficult to categorise as cultural production in the present-day sense. However, we can classify it as a special form of political activity that generated a certain amount of autonomy despite the centralised nature of the People's Liberation Struggle. ${ }^{58}$ Partisan photography's importance lies in this autonomy, because the political language and mechanisms used during the People's Liberation Struggle resulted in an emphasis on its activist potential, which is also important today.

All this means that Partisan photography cannot be labelled as purely propaganda photography. Nor can it be viewed only as a part of the propaganda apparatus. As we have seen so far, while the idea of a centralised system (within which each photography unit would operate) existed from the very beginning, the situation on the ground from 1941 to 1943 was quite different. In this period, Partisan photography existed primarily thanks to the bravery and enthusiasm of key individuals. In the final chapter of the war, 1944 and 1945, a whole series of regulations were passed that attempted to specify the role of photography units within the propaganda system. This came fully into force only after the end of the war in 1945 when many photographers stopped working or volunteering. Photographers' materials then fell under the control of a centralised archive. The entire 
system's centralisation was strongly influenced by the new state's consolidation of the levers of power, along with the foreign office's security assessments warning of a potential Soviet occupation. Only after Cominform's resolution and the split with the USSR did Yugoslavia throw out 'dogmatic views in the field of education and culture taken on from the Soviet experience'. 59 